\title{
Prywatne może być publiczne? Vouchery - najbardziej radykalna forma prywatyzacji amerykańskiej edukacji
}

\section{KEY WORDS}

privatization in education, voucher, choice of school

\begin{abstract}
Potulicka Eugenia, Prywatne może być publiczne? Vouchery - najbardziej radykalna forma prywatyzacji amerykańskiej edukacji [Private Might Be Public? Vouchers - the Most Radical Form of Privatization in American Education]. Kultura - Społeczeństwo - Edukacja nr 1 (3) 2013, Poznań 2013, pp. 47-87, Adam Mickiewicz University Press. ISBN 978-83-232-2631-4. ISSN 2300-0422

Privatization is the main theme of educational politics in XXI century. The idea of vouchers is connected with the believe, that if parents can use publicly funded vouchers to cover tuition at the school of their choice, schools will be forced to compete for paying customers and hence will have reason to improve. But those who believe that education is a part of the implicit social contract required for an effective democracy place emphasis on a school system that is free, publicly funded and guided by democratic decisions rather than that the market ones. Against vouchers was even Chief Justice Earl Warren, who have said that the opportunity of an education is a right which must be made available to all on equal terms.
\end{abstract}

\section{Prywatyzacja jako główny temat polityki oświatowej w XXI wieku}

W XXI wieku pojawiła się w Stanach Zjednoczonych nowa idea prywatyzacji szkolnictwa $\mathrm{w}$ formie finansowania kosztów edukacji w szkołach prywatnych w postaci zwolnionych z opodatkowania voucherów i kredytów. Clive Belfield i Henry Levin, autorzy książki Privatizing Educational Choice. Consequences for Parents, Schools and Public Policy (Prywatyzacja wyboru w edukacji. Konsekwencje dla rodziców, szkół i polityki publicznej), którzy twierdzą, że nie są ani obrońcami, ani zwolennikami tej polityki, próbują dokonać jej obiektywnej analizy w sytuacji, kiedy wiele argumentów zwolenników i przeciwników prywatyzacji szkolnictwa ma charakter 
ideologiczny. Faktem jest jednak to, co wskazywała opozycja, że przesuwając 500 miliardów dolarów rządowych nakładów do prywatnych instytucji edukacyjnych, administracja federalna popierała prywatyzację (Belfield, Levin, 2007: 1). Ruch w tym kierunku rodził się między innymi z potrzeby oszczędności w niektórych sektorach państwowych. Przewodniczący Komisji Edukacji stanu Nebraska stwierdził, że 80\% mieszkańców stanu ma dzieci w szkołach prywatnych i nie chce łożyć na publiczne. Miron Lieberman - zagorzały przeciwnik szkół publicznych ogłosił ich śmierć, a prywatyzację nazwał strategią dla przyszłości (Flam, Keane, 1994: 65 i 121).

Wąska definicja prywatyzacji określa, że jest to przekazanie przedsiębiorstwu prywatnemu usług wcześniej finansowanych przez agencje rządowe. Oznacza ona nie tylko dostarczanie usług, ale i politykę tworzenia struktur, ustalania celów i środków ich realizacji; oznacza też, że prywatny dostawca usług jest rozliczany za ich jakość i koszty. Takie rezultaty daje deregulacja - relatywnie rzadka forma prywatyzacji. Prywatyzacja w szerokim sensie oznacza pełen zakres opcji zwiększających prywatną partycypację w dostarczaniu usług. Jej najbardziej rozpowszechnioną formą jest kontrakt, czyli przekazanie przez rząd świadczenia usług sektorowi prywatnemu i kontrakt z prywatną instytucją, która podlega kontroli publicznej (Flam, Keane, 1994: 23 i 29-30).

Belfield i Levin podkreślali, że proces edukacyjny ma komponenty publiczne i prywatne. Obecna dyskusja o prywatyzacji traktuje ją wąsko. Publiczny i prywatny charakter edukacji jest mniej rozłączny niż się wydaje. Autorzy ci rozróżniają pięć kluczowych dymensji prywatyzacji: 1) sponsorowania, 2) zarządzania, 3) finansowania, 4) produkcji i 5) wyników. Najbardziej sprywatyzowaną formą nauczania jest home schooling.

W Stanach Zjednoczonych istnieje około 30000 szkół prywatnych, uczy się w nich w nich 4,6 mln dzieci, co stanowi 10\%-13\% wszystkich objętych edukacją (Betts, 2005: 15). 83\% placówek prywatnych to szkoły wyznaniowe, przede wszystkim katolickie (Belfield, Levin, 2005: 4).

Belfield i Levin przez szkoły prywatne rozumieją placówki prowadzone dla jednostek i przez jednostki, grupy, instytucje poświęcone przede wszystkim realizacji celów prywatnych uczniów i rodziców oraz sponsorów, którzy są ściśle związani z prerogatywami własności prywatnej. Społeczeństwo amerykańskie stopniowo dryfuje w kierunku mozaiki szkół prywatnych i publicznych.

W latach 90. prywatyzacja edukacji miała już dobry klimat w środowiskach finansowych, które są zainteresowane miliardem dolarów wydawanych dziennie na szkoły publiczne. Jest to największy sektor rządowy nietknięty przez prywatyzację.

W eseju o roli rządu w edukacji Milton Friedman konkludował, że stabilne społeczeństwo demokratyczne nie może istnieć bez określonego poziomu alfabetyzacji i pewnego wspólnego zestawu wartości. Szkolnictwo znacznie przyczynia 
się do realizacji tych celów, toteż pewne minimum publicznego finansowania jest uprawnione, ale publiczne finansowanie szkół nie jest argumentem za szkołami państwowymi. Prywatny rynek edukacyjny dostarczy więcej korzyści. By połączyć publiczne finansowanie ze szkołami prywatnymi, proponował wprowadzenie voucherów na pokrycie kosztów kształcenia w tych placówkach (Friedman, 1962: 86-89).

Ruch zwolenników voucherów należy do znacznie szerszej idei wyboru szkoły i oczywiście do prywatyzacji. Wszystkie te pomysły reform miały doprowadzić do fundamentalnych zmian w sektorze szkół publicznych. Prywatyzacja była modelem reformy - przyznaje jeden z twórców jej teoretycznych podstaw, Terry Moe (Moe, 2001: 73 i n.).

Idea voucherów jest najbardziej kontrowersyjną próbą wprowadzenia zmian edukacyjnych w Stanach Zjednoczonych. Stanowi radykalną reformę neoliberalną i takiż sposób prywatyzacji publicznego sektora oświaty. Oznacza zwiększenie publicznego finansowania kształcenia $w$ placówkach prywatnych kosztem publicznych (Rust, James, 2005: 236). Nawet gorący zwolennik voucherów - Miron Lieberman - przyznaje, że bezpośrednio lub pośrednio szkoły prywatne otrzymają 26\% swoich dochodów ze źródeł publicznych (Liebermann, 1986: 192).

Zdaniem Briana Gilla, Michaela Timpanea i Dominica Brewera (Gill, Timpane, Brewer, 2001: 56-57) vouchery i szkoły czarterowe są najważniejszą i najbardziej dalekosiężną formą polityki wyboru szkoły przez rodziców. Obydwie formy prywatyzacji stanowią fundamentalne wyzwanie dla całego systemu edukacji, przede wszystkim dla modelu wspólnej szkoły. Polityczny ruch voucherów dał nowy impuls ruchowi wyboru szkoły i stał się motorem nowej polityki oświatowej (Moe, 2001: 67-68). Zdaniem jej zwolenników stanowił najważniejszą propozycję zmian mających na celu udoskonalenie edukacji poprzez zmiany w strukturze zarządzania. Lieberman ubolewał, że w większości dokumentów dotyczących reform w oświacie propozycja nie była nawet wspomniana (Lieberman, 1986: 12 i 179). Minister William Bennett popierał vouchery, ale nie było ich w propozycjach budżetowych na rok 1986 (West, 2006: 176).

John Chubb i Terry Moe - twórcy idei ruchu wyboru szkoły - twierdzą, że różnice między placówkami prywatnymi i publicznymi nie są tak duże, jak wielu sobie wyobraża. Większość szkół prywatnych wyróżnia przede wszystkim to, iż są wyznaniowe, a nie elitarne. Ponadto są one bardziej zintegrowane i homogeniczne pod względem zdolności uczniów, rozpiętość ocen jest w nich mniejsza. 54\% szkół publicznych i 41\% prywatnych ma uczniów jednej rasy (Chubb, Moe, 1997: 145). Inne cechy placówek prywatnych to: mniejsza liczba uczniów - przeciętnie 210 (w publicznej 547), mniej liczne klasy, bardziej uporządkowane środowisko, lepsza więź z rodzicami i więcej zadań domowych (Howell, Peterson, 2002: 101). Andrew Coulson twierdzi, że istnieje duży kontrast w podejściu rodziców tych dwu sektorów szkolnych do edukacji. Ci z placówek publicznych uważają, iż ich 
obowiązkiem jest ubranie dziecka i odprowadzenie go do autobusu. Często czują się bezradni wobec systemu edukacji i narasta w nich apatia (Coulson, 1999: 97). Ankietowani rodzice afroamerykańscy mówią o różnicach między szkołami prywatnymi i publicznymi (Howell, Peterson, 2002: 113). Powyższe wypowiedzi wskazują na różnice między tymi sektorami szkolnymi, które chcą zacierać Chubb i Moe. Próbę zatarcia różnic między samym pojęciem szkoły publicznej i prywatnej podejmuje Paul Hill, mówiąc, że w dłuższym okresie szkoły w systemie wyboru finansowane $\mathrm{z}$ funduszów publicznych staną się publicznymi, ponieważ będą regulowane (Hill, Pierce, Guthrie, 1997: 83-84).

Ten punkt opracowania sygnalizuje próbę zacierania granic między publicznym i prywatnym sektorem edukacji, a także znaczenia pojęć „szkoła publiczna”, „szkoła prywatna”. Różnice między tym, co publiczne, a tym, co prywatne i tym, co osobiste, są zacierane, odwracane, a w końcu usuwane (Haman, 2009: 39). Apelujący o wyklarowanie języka i logiki reform Seymour Sarason - dobrze znany polskim psychologom - sam zamazuje znaczenia tych pojęć. Jego zdaniem reforma voucherów jest $\mathrm{w}$ pełni spójna $\mathrm{z}$ popieraniem celów publicznej edukacji, to znaczy dostępnych dla wszystkich możliwości uczenia się i wdrażania do podzielania najważniejszych wartości amerykańskich (Sarason, 2001: viii). Na tej między innymi podstawie Kevin Smith i Kenneth Meier stwierdzają, że jakość edukacji nie jest problemem, ponieważ zdecydowana większość sondaży wskazuje, że żądania klientów są już zaspokojone przez szkoły publiczne (Smith, Meier, 1995: 123-124).

Środowisko pedagogów postrzega prywatyzację jako możliwość wykonywania świadczeń publicznych bez brania pod uwagę konsekwencji ciągle pogarszającej się ich jakości. Postrzega ją jako ideologiczną presję w kierunku zmniejszenia roli rządu (Flam, Keane, 1994: 22). Lord Dahrendorf, dyrektor London School of Economics, stwierdził, że „Uczynienie wartości komercyjnych 'imperatorem naszych dusz' prowadzi do destrukcji przestrzeni publicznej i osłabienia edukacji publicznej" (Flam, Keane, 1994: 29). Amerykanie chcą obniżenia kosztów usług i mniejszej kontroli ze strony władz. W tym zakresie wyraźnie zmieniły się poglądy. Niemniej jednak konieczne jest przemyślenie, które usługi muszą być świadczone przez rząd. Toczą się fundamentalne debaty o wizji i misji edukacji. Społeczeństwo zastanawia się, czego powinno się oczekiwać od edukacji publicznej. Nawet Nathan Glazer, znany profesor Harvardu i wieloletni zwolennik szkół dla wszystkich, doszedł do wniosku, że szkoły publiczne nie są zdolne zaspokoić odmiennych potrzeb i oczekiwań obywateli: religijnych i świeckich, postępowych i tradycyjnych, szukających nowych doświadczeń lub bezpieczeństwa i stabilności (Glazer, 2003: 100). W dyskusji podnoszony jest też aspekt ekonomiczny. Finansiści przyczyniali się do stwarzania wrażenia, że nauczyciele są za dobrze opłacani (Flam, Keane, 1994: 36). 


\section{Argumenty zwolenników voucherów}

Koncepcję voucherów po raz pierwszy przedstawił Milton Friedman w roku 1955. Jego intencją było zwiększenie produktywności szkolnictwa oraz rozwiązanie problemu państwowego monopolu kontrolującego instytucje edukacyjne. Zdaniem Friedmana administracja oświatowa jest mało zainteresowana dostarczaniem jak najlepszych produktów za jak najniższą cenę. Jeżeli rodzice będą mogli korzystać z finansowanych przez państwo voucherów na pokrycie całych lub części kosztów kształcenia w szkołach prywatnych, to placówki publiczne będą zmuszone do konkurowania i zabiegania o uczniów oraz do doskonalenia pracy, zwiększania produktywności, efektywności finansowej i spełniania oczekiwań klientów. Rose i Milton Friedmanowie utworzyli fundację, której celem było uchwalenie prawa wprowadzającego vouchery oraz inne formy wyboru szkoły do systemu edukacji publicznej (Howell, Peterson, 2006: xi-xii). Jednak w latach 70. żaden stan nie chciał dawać publicznych pieniędzy dla szkół prywatnych, nawet $\mathrm{z}$ pomocą federalną.

Prezydent George Bush włączył dymensję wyboru szkoły przez rodziców do działań na rzecz poprawy stanu amerykańskiej edukacji. Poprzez mocny nacisk na wybór nadał on kształt agendzie narodowej. Była to idea atrakcyjna dla rodziców, uczniów i polityków. Bush sądził, że jest to rozwiązanie niepociągające za sobą zwiększania kosztów (Berube, 1991: 131-132). Było to według niego panaceum na rozwiązanie problemów edukacji, idea prosta i najbardziej obiecująca. Uważał, że dalsze jej rozwijanie jest narodowym imperatywem.

Minister edukacji Lauro Flavazos podkreślał, że wybór wzmocni indywidualizm uczniów, wstrzyma porzucanie nauki przez młodzież, zwiększy zaangażowanie rodziców w życie szkoły, pomoże „edukacyjnie biednym” i zrekonstruuje szkolnictwo publiczne. Najważniejszym argumentem na rzecz wyboru szkoły przez rodziców była jednak nadzieja na poprawę osiągnięć uczniów; to był także główny argument polityczny. Oczekiwano też zwiększenia różnorodności oferty edukacyjnej oraz większego zaangażowania rodziców i uczniów, odbudowy głównej zasady demokratycznej (Berube, 1991: 134).

Teoretyczną podstawę koncepcji voucherów opracowali John Chubb i Terry Moe. Zawarli ją w książce Politics, Markets and America's Schools (1990). Akcentowali oni politykę prywatyzacji, która miałaby otoczyć sektor szkolnictwa publicznego, i wejść z nim w proces dyfuzji. Ich zdaniem zarządzający tym sektorem są pod wpływem presji szeregu grup interesów. Władza przesuwa się od jednej grupy do drugiej i formułuje w związku z tym żądania będące ze sobą w konflikcie. Powoduje to sytuację, w której szkoły publiczne nie mogą sformułować jasnej i spójnej misji edukacji.

Szkoły prywatne są skupione na ich zadaniach edukacyjnych i dzięki temu osiągają lepsze efekty. Mają jasno określone cele, rygorystyczne standardy akade- 
mickie, panuje w nich porządek i dyscyplina, dużo jest zadań domowych, wysokie są oczekiwania wobec osiągnięć uczniów, silne jest w nich przywództwo dyrektora, nauczyciele uczestniczą w podejmowaniu decyzji i mają dobry kontakt z rodzicami. Kurator i administracja mniej kontrolują program nauczania, metody, zatrudnianie nauczycieli i standardy dyscypliny. $60 \%$ szkół miało ponadśredni poziom autonomii. Mogły one dyscyplinować lub skreślać z listy uczniów sprawiających kłopoty wychowawcze (Chubb i Moe, 1990: 16; Hess, Loveless, 2005: 93). Ci entuzjaści wolnego rynku w edukacji odnotowali szczególnie duże różnice między placówkami prywatnymi i publicznymi w śródmieściach wielkich metropolii, z dominacją mniejszości rasowych i etnicznych. Jednak nie badali opisywanych sektorów oświaty, nie dokonywali empirycznych porównań - za co byli krytykowani.

Argumenty za wprowadzeniem voucherów przedstawiał też Miron Lieberman. Stwierdził, że prawo daje rodzicom możliwość wybierania dla dzieci nauczania w szkołach prywatnych. Wolność konsumenta jest ważną wartością w społeczeństwie amerykańskim, przeciwstawia się monopolowi. Vouchery zwiększą możliwość wyboru szkoły, bo zmniejszą obciążenia finansowe rodziców. Polityka społeczna powinna sprzyjać różnorodności szkół odpowiadających preferencjom rodziców. Wzmocnienie możliwości wyboru jest postrzegane jako wprowadzenie koniecznej rynkowej dymensji do edukacji. Pomoc rządu w postaci voucherów będzie kosztowała mniej niż kształcenie w szkołach publicznych, ponadto szkoły wybrane przez rodziców będą integrowały dzieci różnych ras (Liebermann, 1986: 198).

Rozważając kwestię oszczędności, National School Boards Association zauważyło, że jako najważniejszy powód prywatyzacji wskazywało je co prawda $45 \%$ respondentów, ale tylko $1 / 3 \mathrm{z}$ tej grupy stwierdziła, że pewne oszczędności miały miejsce (NSBA, 1995: 11). Oszczędności w sektorze prywatnym mają wszakże miejsce między innymi dlatego, że prywatne szkoły nie respektują zbiorowych układów pracy wywalczonych przez związki nauczycielskie, mogą zatrudniać nauczycieli bez licencji i mniej im płacić. O ile w kraju przeciętnie na jednego ucznia szkoły publicznej wydaje się 6900 dolarów, to w prywatnej poniżej - 4000 dolarów. Nauczyciele w szkołach prywatnych zarabiają średnio 25000 dolarów rocznie, a w publicznych więcej niż 40000 dolarów rocznie, twierdzą Howell i Peterson (Howell, Peterson, 2002: 8). Ponadto placówki prywatne praktykują nauczanie całej klasy jednym frontem ze względu na jego efektywność w sensie ekonomicznym (Hess, Loveless, 2005: 90-94).

Andrew Coulson, autor książki o wyborze szkoły i przeciwnik wpływu państwa na edukację, akcentował przede wszystkim argument, że wybór rodziców uwolni szkołę od niektórych stanowych regulacji i zachęci szkolnictwo do specjalizowania się w określonych dziedzinach. Jego zdaniem w roku 1992 rodzice generalnie byli zwolennikami wyboru - w szkołach publicznych w 76\%, w prywatnych w $84 \%$, a tylko niektórzy uważali, iż zwiększa on możliwości jednych uczniów kosztem drugich. Ci ostatni nie akceptowali voucherów (Coulson, 1994: 18-19). 
Wybór rodziców, konkurencja między szkołami, czynnik zysku - w istocie wolny rynek w edukacji - to, zdaniem Coulsona, recepta na sukces. Nie ma dowodu, że biedni czy niezaradni rodzice dokonają gorszego wyboru niż nauczyciele. Proponuje on wręcz, by zmusić rodziców do samodzielnego podejmowania decyzji. Tylko wtedy uniknie się podwójnego trudu wyzwolenia się spod prawa, regulacji, biurokracji i szkół publicznych (! - E. P.). Vouchery czy uniwersalne stypendia rządowe spowodują znacząco lepszą pracę w zaspokajaniu potrzeb edukacji publicznej. Zmiana powinna polegać na przejściu od prowadzenia szkół przez rząd do fundowania stypendiów. Będzie to krok zbliżający do doskonałości edukacji (Coulson, 1994: 293-295 i 324).

Chubb i Moe ożywili publiczne zainteresowanie wyborem szkoły. Ich punkt wyjścia był trochę inny niż Friedmana, który kładł nacisk przede wszystkim na efektywność rynku edukacyjnego. Był też inny niż punkt wyjścia Jencksa, zainteresowanego upełnomocnieniem najmniej uprzywilejowanych obywateli.

Zdaniem tych autorów szkoły najlepiej funkcjonują, mając jasną misję, dysponując autonomią oraz elastycznością w wyborze sposobów realizacji celów. W przypadku zarządzania sektorem publicznym przez władze centralne misja jest podporządkowana wąskim zasadom naszkicowanym przez grupy interesów i kadrę szkolną. Rezultaty są porażające - twierdzą. Chubb i Moe dążyli do utworzenia systemu będącego prawie całkowicie poza zasięgiem władzy publicznej (Mittang, Connell, 2001: 217). Było to - ich zdaniem - panaceum na problemy amerykańskiego szkolnictwa. Ma rację Michael Apple, że była to próba niszczenia edukacji publicznej (Apple, 2001).

W systemie wolnorynkowym przedsiębiorca może dowolnie określać swoją misję, a na jego decyzje znaczący wpływ wywiera konsument. Vouchery pozwolą rodzicom wybrać szkołę najbardziej odpowiadającą ich dziecku. Szkoły będą konkurowały między sobą, będą pod stałą presją doskonalenia swojej pracy, by zaspokajać żądania konsumentów - kontynuowali Chubb i Moe (Chubb, Moe, 1990: 15). Ci dwaj autorzy oraz Friedman osadzili propozycję wyboru szkoły w teorii rynku. Klasyczna teoria ekonomii zakłada, że perfekcyjnie konkurencyjny rynek prowadzi do optymalnych rezultatów społecznych (Betts, 2005: 16).

Jako teoria pozytywna (wyjaśniająca, jak świat funkcjonuje) rynek jest formalizowany w teorii publicznego wyboru. Koncepcja wyboru szkoły czerpie z teorii ekonomicznej, która opracowała matematyczny model korzyści na rynku, biorąc pod uwagę różne założenia o nasileniu konkurencji na danym rynku. Programy wyboru tworzą konkurencyjny rynek zmuszający szkoły do rywalizowania o uczniów. Teoria ekonomiczna dostarcza narzędzi do analizy mechanizmów, które mogą zredukować obawy przed wdrożeniem tej koncepcji - obawy, że spowoduje to duże zróżnicowanie jakości edukacji, którą otrzymają uczniowie (Betts, 2005: 14-15). Teoria publicznego wyboru jest jedną z neoliberalnych koncepcji, w której w istocie chodzi o wybór indywidualny, a nie publiczny (Morrow, Torres, 1999: 99). 
Martin Carnoy i Henry Levin twierdzą, że teoria konfliktów między społeczeństwem i państwem dostarcza ram do dialektycznej analizy edukacji w społeczeństwie kapitalistycznym, ponieważ poglądy na ruchy społeczne odgrywają istotną rolę, wpływając na politykę społeczną. Na tej podstawie można przewidywać skutki reformy edukacji, oceniać ich potencjał i trudności (Carnoy, Levin, 1985: 46-47). To podejście pozostaje w większości w obrębie założeń opartych na klasach „starej” teorii ruchów społecznych i ignoruje specyfikę nowych ruchów. Próbę wiązania oraz integracji nowych ruchów społecznych i reform edukacji od lat 80. podejmuje pedagogika krytyczna. Jednak nie odegrała ona znaczniejszej roli (Wexler, 1987: 87-88). Nie miała także wielkiego wpływu na politykę oświatową, znalazła natomiast oddźwięk w różnych ruchach społecznych i była częścią procesu mobilizacji politycznej (Morrow, Torres, 1999: 103-105).

Teoria ekonomiczna analizuje dwie skrajności: monopol i konkurencję. Konkurencja pojawia się wtedy, gdy liczba kupujących i sprzedających jest bardzo duża. Rynek jest efektywny, ponieważ nie marnuje zasobów. Indywidualni producenci i konsumenci podejmują optymalne decyzje w wysoce zdecentralizowany sposób. Niektóre konieczne warunki zaistnienia perfekcyjnej konkurencji to: możliwość równego sprzedawania wszystkim klientom przez firmy, maksymalizacja zysku przez firmy i maksymalizacja korzyści/prywatnych interesów przez konsumentów. Poprawa osiągnięć uczniów bez pogarszania ocen innych to „piękno perfekcyjnie konkurencyjnego rynku” - gloryfikuje jego zalety Julian Betts, ekonomista. Nie jest wszakże prawdopodobne, by tego rodzaju konkurencja zaistniała w szkolnictwie (Betts 2005: 16, 19, 26). Niemniej wdrożenie teorii publicznego wyboru uczyni funkcjonowanie systemu szkolnego zbliżonym do rynkowego. Jego niewidzialna ręka przyniesie korzyści wszystkim (Goldhaber i in., 2005: 105).

W przypadku monopolu szkolnego nie ma możliwości wybierania instytucji odpowiadającej preferencjom rodziców czy uczniów. Produkcja jest wówczas mniej efektywna.

Wybór szkoły najlepiej postrzegać w kategoriach szeregu rynków oferujących różnego rodzaju nauczanie. Gdyby istniała wystarczająca liczba szkół prowadzących każdy typ nauczania, wówczas byłoby blisko do konkurencji perfekcyjnej. Teoria konkurencji pokazuje, że na kontinuum od perfekcyjnej konkurencji do monopolu pewna konkurencja jest prawie zawsze lepsza dla konsumentów niż jej absolutny brak. Jeżeli wszyscy rodzice poszukują najlepszej szkoły dla swoich dzieci, to nie ma znaczenia, czy działa ona dla zysku (Betts, 2005: 22-25).

Większy wybór prowadzi do pozytywnych zmian systemowych. Dostawcy edukacji będą wkraczali na rynek, by zaspokoić każde zwiększające się zapotrzebowanie. Model przewiduje, że będzie ona organizowana efektywnie dzięki rygorystycznej konkurencji, co nie znaczy, że będzie dostarczana sprawiedliwie - przyznają Betts, Goldhaber i Rosenstock (Betts, Goldhaber, Rosenstock, 2005: 72). 
Każdy program reformy edukacji musi zaplanować, co robić ze szkołami upadającymi. „Geniusz konkurencyjnych rynków polega na tym, że takie placówki wypadają z rynku” - znowu idealizuje Betts (Betts, 2005: 25). Koncepcja wyboru szkół świadomie zachęca uczniów do opuszczania nieatrakcyjnych placówek. W coraz większym stopniu patrzy się na rynek jako na rozliczającego (Jones, 2000: 39).

Chubb i Moe twierdzili, że vouchery zapewnią lepszą edukację przy mniejszych lub podobnych kosztach (Chubb, 2006: 13-14), albo lepszą przy tych samych kosztach (Levin, 2006: 23). Wszakże, o ile w szkołach prywatnych czynnikiem motywującym dostawcę edukacji jest zysk, o tyle w przypadku voucherów cena jest zdeterminowana przez władze polityczne (Betts, Goldhaber, Rosenstock, 2005: 70). Jednak Betts i Loveless logicznie stwierdzają, że program wyboru szkoły nie jest programem edukacyjnym w tym sensie, że nie promuje nowego podejścia do nauczania. Zwykłe dokonanie wyboru nie poprawia nauczania (Betts, Loveless, 2005: 6). Moe przyznaje, że program voucherów był motywowany ideałem władzy rynku w naprawianiu szkolnictwa (Moe, 2006: 147).

Zalety wolnego rynku są ciągle atrakcyjne. Mark Zupan twierdzi, że jest ich wiele. Najbardziej rozpoznawalne to eksponowanie indywidualnego wyboru i wolności. Rynek promuje siłę charakteru i wzajemnie korzystną wymianę. Wolny rynek cywilizuje, a nie brutalizuje. Interakcje na rynku mogą być powtarzane i prowadzić do współpracy (Zupan, 2012: 177 i 194). System wyboru rodziców w edukacji zachęca ich oraz uczniów do dokonywania mądrych wyborów.

Argumenty za wprowadzeniem voucherów zakorzeniły się także w teorii kapitału społecznego, która rozwinęła się później. Zdaniem jej zwolenników uczniowie uczą się lepiej, kiedy rodzice i nauczyciele współpracują ze sobą. W usługach, które są kooperacją rządu i obywateli, kapitał społeczny jest ważnym źródłem efektywności. Kapitał społeczny uczniów pozwoli im lepiej wypełniać obowiązki.

Spadek kapitału społecznego może mieć szczególnie niszczące konsekwencje w edukacji. Rodzice ze śródmieść metropolii stają się coraz bardziej anonimowi, a szkoły coraz mniej są związane ze społecznością lokalną. Wybór szkoły przez rodziców może być rozwiązaniem problemu braku kapitału społecznego - stwierdzają William Howell i Paul Peterson (Howell, Peterson, 2006: 16-17). Jednak zdania dotyczące motywów wybierania szkoły są przeciwstawne. Według Carnegie Foundation for Advancement of Teaching jakość szkoły nie jest najważniejszym czynnikiem podczas wyboru (School choice..., 1992: 13). Rodzice biorą pod uwage dojazd do szkoły, wyznanie religijne i status socjo-ekonomiczny kolegów ich dziecka (Smith, Meier, 1995: 123-124). Z kolei Mark Schneider uważa, że rozważając wybór szkoły, rodzice podkreślają jej aspekt edukacyjny: jakość pracy nauczycieli i oceny z testów. To są dla nich najważniejsze kryteria wyboru (Schneider, Teske, Marshall, 2000: 94). Tucker dodaje do nich dyscyplinę w szkole i bezpieczeństwo jako kryterium wymieniane na pierwszym miejscu (Tucker, 2004: 138). Myślę, że te kryteria zależą od grupy rodziców, np. bezpieczeństwo może być szczególnie 
ważne dla Afroamerykanów ze względu na jego brak w szkołach metropolii. Niektóre szkoły śródmiejskie są zdominowane przez gangi uliczne. Odcięcie dzieci od tego środowiska może być dla rodziców najbardziej oczekiwaną korzyścią edukacyjną (Howell, Peterson, 2002: 126).

Rozwiązanie problemów szkół w śródmieściach metropolii jest bardzo trudne. Obowiązującą desegregację społeczną uniemożliwia przeprowadzanie się ludności białej na przedmieścia lub na wieś. Na skutek tego procesu szkoły średnie są tak posegregowane, jak w latach 70 . Obietnice testowania uczniów i rozliczania szkół - ubolewają zwolennicy voucherów - pozostają niespełnione. Decentralizacja i kontrola społeczności lokalnej mogą tylko pogorszyć sytuację.

Argumentem na rzecz wprowadzenia voucherów, który wysuwają ich zwolennicy, jest przede wszystkim potencjalne wyrównywanie możliwości edukacyjnych. Ale jest nim także mantra neoliberalizmu - konkurencja, zwiększanie kapitału społecznego i usunięcie polityki z edukacji. Vouchery oraz inne formy wyboru szkoły miałyby skupić się na zorganizowaniu nowych możliwości szkolnych dla rodziców o niskich dochodach, wykluczonych społecznie, zwłaszcza dla szukających wystarczająco dobrej placówki w centrach metropolii. Problemy wielu szkół $\mathrm{w}$ obszarach zurbanizowanych są dobrze udokumentowane: pracują $\mathrm{w}$ nich niedoświadczeni nauczyciele, uczniowie są niezdyscyplinowani, ich oceny niskie oraz niski odsetek wypromowanych absolwentów szkół średnich, którzy nie znajdują zatrudnienia lub trafiają do więzienia.

Inna teoria, leżąca u podstaw idei voucherów, to teoria kapitału ludzkiego. Zaadoptował ją Bank Światowy (Heyneman, 2005: 325). Akcentuje się w niej prywatne inwestycje $\mathrm{w}$ edukację, co $\mathrm{z}$ kolei prowadzi do osłabienia publicznej kontroli nad szkolnictwem (Berman, 1999: 257). Biznesmeni amerykańscy w raporcie Investing in Our Children podkreślali, że zasoby ludzkie są ważniejsze niż materialne. Robert Reich, minister pracy i doradca ministra edukacji, również akcentował kapitał ludzki (Smith, Scoll, 1995: 390), podobnie jak kolejne rządy (Spring, 2008: xii). Korporacje coraz częściej penetrowały szkolnictwo publiczne. Zakres i głębia zmian wprowadzonych w kolejnych reformach amerykańskich nie może być przypisana spontanicznemu niezadowoleniu z wyników dotychczasowej edukacji. Był to świadomy wysiłek części niezwykle mocnych grup interesów (Berman, 1999: 274 i 287). Do głównych krytyków teorii kapitału ludzkiego należą organizacje praw człowieka (Spring, 2008: 351).

Kiedy inne próby poprawy sytuacji w rejonach zurbanizowanych zawiodły, zwolennicy voucherów nasilili argumentację egalitarną na rzecz ich wprowadzenia (Howell, Peterson, 2002: xiv). Poprzednio akcentowali potencjał voucherów w zakresie zwiększania produktywności, ale niemal z dnia na dzień zaczęło się to zmieniać. Zarzucano placówkom publicznym, że nie konkurują o nauczanie dzieci z rodzin o niskim statusie społeczno-ekonomicznym, wypychają uczniów biednych ze szkoły lub zachęcają do jej opuszczenia przed ukończeniem eduka- 
cji na poziomie średnim. Liderzy ruchu wyboru szkoły głosili tezę, iż szkolnictwo publiczne poniosło porażkę $\mathrm{w}$ nauczaniu dzieci $\mathrm{z}$ rodzin ubogich i dało im nieodpowiednią edukację (Natriello, 2001: 264). Vouchery jako formę wyboru szkoły przez rodziców zalegalizowano w stanach Wisconsin, Ohio, Floryda (Jeb Bush - brat prezydenta), a w Nowym Yorku liderzy finansjery i filantropii założyli w tym celu School Choice Scholarship Foundation (fundującą stypendia na wybór szkoły). Prywatny sponsoring voucherów szybko się rozpowszechniał. Zdaniem Chubba i Moe vouchery są narzędziem sprawiedliwości dla biednych, krokiem w kierunku równego dostępu do edukacji. Teoria wyboru publicznego głosi, że ta forma prywatyzacji rozszerza możliwości wyboru na rodziny, które nie mogły sobie pozwolić na zmianę miejsca zamieszkania czy kształcenie dzieci w szkołach prywatnych. To spowoduje, że fundamentalnie zmieni się krajobraz szkolny (Betts, Loveless, 2005: 2). Skutki wyboru dla całego systemu szkolnego to efektywne rozmieszczenie uczniów odpowiednio do potrzeb, zainteresowań i stylów uczenia się. Uczniowie znajdą się w społecznościach uczących się zgodnie z indywidualnymi potrzebami. Wybór będzie stymulował lojalność rodziców i uczniów wobec szkoły oraz zaangażowanie, co będzie wspierało dążenie do lepszych osiągnięć (Goldhaber i in., 2005: 101-102).

Zgodnie $\mathrm{z}$ analizowaną teorią możliwe jest, iż programy wyboru szkoły dadzą korzyści również tym, którzy nie dokonują wyboru. Wybór szkół może bowiem uruchomić dynamikę wpływającą pozytywnie na wszystkich. Uczniowie niedokonujący wyborów mogą znaleźć się w szkołach z młodzieżą podobną do nich. Wówczas strategia nauczania może być lepiej dostosowana do ich możliwości. W systemie wyboru grupowanie uczniów według zdolności będzie bardziej akcentowane. Nieuregulowany wybór nie jest zgodny z dobrą polityką publiczną, stwierdza Betts (Betts, 2005: 26-38). Jednak szkoły przyjmujące uczniów z voucherami nie mogą praktykować dyskryminacji. Natomiast za większą liczbą uczniów powinno iść większe finansowanie oraz nagrody, a szkołom tracącym uczniów należy zmniejszyć nakłady (Goldhaber i in., 2005: 122). Tylko znaczące i bezpośrednie nagrody mogą skłonić do przyjęcia większej liczby uczniów.

Koncepcja wyboru szkoły sama w sobie nie jest ani dobra, ani zła - twierdzi Goldhaber, natomiast niesie ze sobą dobre albo złe konsekwencje, zależnie od specyficznych warunków. System publiczny może nie reagować na presję rynku, ale może być motywowany presją polityczną artykułowaną przez elektorat, grupy interesów i kanały biurokratyczne (Goldhaber, 2005: 102-103).

W programie voucherów przyjęto model „złotej zasady”: voucher stanowić będzie połowę kosztów opłaty za nauczanie w szkole prywatnej. Przyznawano je także dla uczniów szkół prywatnych, których rodzice byli za biedni, by w całości pokryć czesne (Moe, 2001: 80). Gorący zwolennik voucherów - John Merrifield (Merrifield, 2001: 162) - twierdzi, że ich przeznaczenie dla dzieci z rodzin o niskich dochodach może być zmianą rewolucyjną. Rodziny takie po raz pierwszy 
mogą dokonać wyboru szkoły. Oficjalnym celem była pomoc małej liczbie uczniów $\mathrm{z}$ takich rodzin w zdobyciu lepszej edukacji. Terry Moe z dumą podkreślał, że vouchery były perfekcyjnym wehikułem nowej polityki oświatowej. Wokół ich idei zjednoczyła się nieortodoksyjna koalicja konserwatystów oraz rodzin o niskich dochodach. On oraz inni zwolennicy prywatyzacji szkolnictwa mówili, że z jednej strony był to ruch filantropijny, ale z drugiej strony szedł znacznie dalej jako ruch polityczny.

W latach 90. zwolennicy voucherów znaleźli dodatkową drogę - powiązanie ich z potrzebami uczniów z niepełnosprawnościami. Moe przyznał, że edukacja specjalna znacznie zwiększyła możliwości prywatyzacji w postaci voucherów. Na Florydzie 350000 uczniów z niepełnosprawnościami było uprawnionych do tej formy pomocy (Moe, 2006: 150-151). Ta inicjatywa ujawniła ogromną potrzebę wyboru szkoły wśród rodziców o niskich dochodach. W samym Nowym Jorku około 20000 uczniów wyraziło zainteresowanie uzyskaniem stypendium Children's Scholarship Fund, w skali kraju około 1 miliona.

Rzecznicy voucherów powołują się także na wyniki badań Jamesa Colemana wskazujące na to, że brak wyboru szkoły nie eliminuje stratyfikacji uczniów. W systemie edukacji, który jest aktualnie bardzo ustratyfikowany wprowadzenie wyboru szkoły nie nasili tego procesu, tylko zmieni jego miejsce (Coleman, 1992: 260-262). Zróżnicowanie miejsc zamieszkania może skutkować szkołami publicznymi ustratyfikowanymi podobnie, jak placówki prywatne.

Howell i Peterson twierdzą, że w obecnie funkcjonującym systemie edukacji publicznej - zgodnie z ich teorią zróżnicowanego wyboru szkoły - większość rodziców określa swoje opcje poprzez wybór miejsca zamieszkania, na które moga sobie pozwolić. Prawdopodobny wpływ interwencji politycznej, takiej jak vouchery, zależy od sukcesów rodziców w praktykowaniu wyboru w obrębie istniejącego systemu. Dla tych, którzy nie mogą sobie pozwolić na przeprowadzkę do dzielnicy z dobrą szkołą, vouchery mogą stwarzać wartościową opcję kształcenia w szkole prywatnej. Rynek nieruchomości (od których zależy wysokość podatków odprowadzanych do władz lokalnych) kreuje nieprawdopodobne nierówności. Teoria zróżnicowanego wyboru przewiduje, że wpływ voucherów będzie się znacząco różnił dla Afroamerykanów oraz innych grup etnicznych (Howell, Peterson, 2002: xxiv).

Vouchery mogą nie tyle wprowadzić wybór w edukacji, ile zredukować jego zależność od rynku nieruchomości, rozbić więź między miejscem zamieszkania a szkołą. Howell i Peterson oferują inne myślenie o wyborze szkoły. Teoria zróżnicowanego wyboru zakłada inne formy wyboru szkół, z różnym wpływem na różne grupy społeczne. Nowe możliwości edukacyjne mogą dać największe korzyści grupom, które nie mogą dokonywać wyboru na rynku nieruchomości. Krytycy voucherów przyznają, że system oświatowy skonstruowany tak, jak obecnie, jest systemem wyboru szkoły. Placówki te służą bardzo zróżnicowanym społeczno- 
ściom. Tam, gdzie znajdują się wyjątkowo dobre szkoły, rosną ceny nieruchomości - i odwrotnie.

Wybór poprzez selekcję miejsca zamieszkania odpowiada także teorii rynku. Taka selekcja jest bardzo nieegalitarna, stwierdzają Howell i Peterson. Najmniejszy wybór rezydencji mają Afroamerykanie. Duże jest prawdopodobieństwo ich zamieszkiwania w śródmieściach wielkich metropolii, w lokalach poniżej standardów, w dzielnicach zagrożonych przestępstwami kryminalnymi, ze zdegradowanym środowiskiem i gorszymi szkołami. Wyposażenie tych szkół jest poniżej standardów, możliwości finansowe bardzo małe, prowadzące do porażki - stwierdził kurator nowojorskich szkół śródmiejskich Harold Levy (Howell, Peterson, 2002: 91). Rezultat netto czynników ekonomicznych i dyskryminacji rasowej to bardzo posegregowany rynek nieruchomości. Rasa nadal jest ważnym czynnikiem wpływającym na wybór miejsca zamieszkania.

Ze względu na szkołę do innych dzielnic przedmiejskich lub na wieś przeprowadza się 45\% Białych, 35\% Latynosów i 22\% Afroamerykanów (Moe, 2001). Dla tych ostatnich wybór szkoły poprzez wybór miejsca zamieszkania nie istnieje. Szkoły publiczne dziedziczą nierówności rasowe rynku nieruchomości (Clotfelter, 2001: 202; Belfield, Levine, 2005: 21). Konsekwencje pedagogiczne takiego stanu rzeczy mogą być tylko niszczące. Na poziomie podstawowym czyta tylko $23 \%$ uczniów z biednych szkół śródmiejskich, a 46\% uczniów z rodzin o niskich dochodach na obszarach wiejskich. Przepaść w ocenach z testów powiększa się w miarę upływu lat pobytu w szkole. W latach 90. pogłębiła się.

Wielu zwolenników neoliberalnych reform oświatowych twierdzi, że duża część badań dotyczących wydatków szkolnych wykazuje małe powiązanie nakładów na edukację z tym, ile uczą się dzieci i młodzież, w najlepszym przypadku słabo wiążą się z osiągnięciami szkolnymi - twierdzi Eric Hanusek, główny rzecznik tej tezy i dostarczyciel „argumentów” dla jej potwierdzenia (Hanushek, 1996: 69). Dowodem mają być między innymi nakłady na jednego ucznia szkoły publicznej, które w roku 1993/94 wynosiły przeciętnie 6100 dolarów, w szkole prywatnej - 3380 dolarów i katolickiej - 2378 dolarów. Ponadto Hanushek twierdzi, że w latach 1973-1996 wyniki amerykańskich uczniów z czytania pogorszyły się, a z matematyki nie zmieniły. Natomiast nakłady na szkoły publiczne zwiększyły się w tym czasie o 45\%. Jak twierdzi, wielu komentatorów przypisuje pogorszenie się ocen nieefektywnemu zarządzaniu systemem edukacji przez rząd i brakowi konkurencji. Nauczyciele placówek publicznych zarabiali o 1/34 więcej niż pedagodzy ze szkół prywatnych (Digest of.. 2000, 2001: 83). Trzeba tu jednak dodać, że oświata publiczna prowadzi szerszą działalność. Tak na przykład w szkołach śródmiejskich nauczyciele są zmuszeni poświęcać dużo czasu na rozwiązywanie problemów społecznych.

Inna entuzjastka wolnego rynku w edukacji i jej efektywności finansowej Caroline Hoxby, profesor ekonomii w Harvardzie - twierdzi, że badania wielko- 
ści klas w stanie Connecticut wykazały mały wpływ tej wielkości na osiągnięcia uczniów (Hoxby 2000: 1239 i n.). Przypomnę jednak, iż w szkołach prywatnych liczebność klas jest mniejsza niż w publicznych.

Większość Afroamerykanów jest lojalna wobec szkoły w miejscu ich zamieszkania. Taki stan rzeczy uwewnętrznia amerykański etos polityczny. Jest on korzystny dla osób dobrze prosperujących, a zarazem zachowane są pozory równości - szkoły są otwarte dla wszystkich.

Caroline Hobby, patrząca na prywatyzację tylko w różowych okularach i gorliwie (co nie znaczy rzetelnie) zbierająca wszelkie „argumenty” na jej rzecz, mówi, że większy wybór rezydencji wiąże się z lepszymi szkołami. Klasy są bardziej ustrukturowane i zdyscyplinowane, rodzice bardziej zaangażowani w sprawy edukacji, oceny z testów są wyższe, a na zajęcia sportowe kładzie się większy nacisk (Hobby, 2000, 2003).

Argumenty za wprowadzeniem voucherów Howell i Peterson osadzają także na tle teorii sprawiedliwości Johna Rawlsa. Powołują się na jego pierwszą zasadę sprawiedliwości, która brzmi: „każda osoba ma równe prawa do najszerszej podstawowej wolności podobnej do wolności innych”, „każda osoba ma mieć równe prawo jak najszerszej podstawowej wolności możliwej do pogodzenia z podobną wolnością dla innych" (Rawls, 1994: 87). Autorzy ci nie podają jednak drugiej zasady sprawiedliwości Rawlsa, zgodnie z którą: „nierówności społeczne i ekonomiczne mają być tak ułożone, by a) można się było rozsądnie spodziewać, że będzie to $\mathrm{z}$ korzyścią dla każdego i b) wiązały się z pozycjami i urzędami na równi dla wszystkich otwartymi”. Jest to tym ważniejsze, iż Rawls zaznacza: „dwie zasady sprawiedliwości ustawione $\mathrm{w}$ hierarchicznym porządku nie pozwalają zamienić podstawowych wolności na zyski społeczne czy ekonomiczne” (s. 90). A „środki na edukację nie mogą być przydzielane wyłącznie, ani przede wszystkim, odpowiednio do spodziewanego zysku w postaci wykształcenia produktywnych umiejętności, lecz także stosownie do jej wartości wzbogacających osobiste i społeczne życie obywatelskie włącznie z najmniej uprzywilejowanymi” (s. 153).

Powołując się tylko na jedną zasadę sprawiedliwości Rawlsa, akcentującą wolność, a pomijając wbrew woli autora teorii drugą zasadę sprawiedliwości - mówiącą o nierównościach społecznych i ekonomicznych - Howell i Peterson wypaczają sens zasady sprawiedliwości i manipulują nią, podkreślając tylko kwestię wolności. Neoliberałowie zwykle podkreślają tę wartość i chętnie szermują słowami o wolności.

Zwolennicy voucherów, których poglądy tu analizujemy, twierdzą, że wolność, równość i edukacja to kanwa amerykańskiej tkanki społecznej. Ich zdaniem polityka Stanów Zjednoczonych ustanawia edukację jako pierwszoplanowe narzędzie promowania i ochrony koncepcji równych możliwości. Jednak wkład edukacji w ich tworzenie w najlepszym przypadku jest ambiwalentny. Paul Peterson pisze, że dotąd vouchery ograniczano do uczniów o niskich dochodach, ale rozszerzenie tego programu nie powoduje zachęcania do segregacji ze względu na dochody 
rodziców. Powinny zmierzać do integracji szkół publicznych i prywatnych, ekonomii i społeczeństwa. By to się stało, powinny być ogólnie dostępne (! E. P., 2006: 19). Promuje się ideę partnerstwa prywatno-publicznego. Harry Patrinos, główny specjalista Banku Światowego do spraw ekonomii i edukacji, przyznaje jednak, że musi ono być ściśle regulowane i kontrolowane (Patrinos, 2012: 164).

Brak dowodów, że takie partnerstwo ma pozytywny wpływ na szkolnictwo, a niektórzy obawiają się potencjalnych szkód. Zagrożenia z tym związane to ograniczenie równości i sprawiedliwości w edukacji, niestabilność i niejasność powiązań, wpływ na system edukacji jako całość. Podstawy partnerstwa są ideologiczne, a gracze mają bardzo nierówną władzę. Biznes ma własne poglądy na to, co jest złe w edukacji. Ostatnie szokujące artykuły pokazały, do jakiego stopnia amerykańska polityka oświatowa jest dyrygowana przez polityków neoliberalnych - fundacje Gatesa, Broad i Waltona. Bardzo ograniczają one publiczne pieniądze na edukację w związku z założeniem, że sektor prywatny pomoże wypełnić braki. Biznesowe know how nie jest potrzebne w edukacji, potrzebne są natomiast podatki od biznesu, by dostarczyć odpowiednie zasoby do szkolnictwa. 30 lat neoliberalnego eksperymentu to katastrofa. Jakość edukacji się pogorszyła, a nierówności w niej powiększyły (Dalton, 2012: 157-161). Tymczasem, mimo że kształcenie uczniów od 6 do 16 roku życia obejmuje niemal wszystkich, to jego jakość bardzo się różni. Biali i Czarni nadal uczęszczają do odmiennych szkół. W roku 1996 70\% Afroamerykanów uczyło się w szkołach z dominacją mniejszości. Prywatyzacja służy prywatnym interesom (Dalton, 2012: 169). Nakłady na jednego ucznia w poszczególnych stanach charakteryzuje rozpiętość od 9600 dolarów w New Jersey do 3800 dolarów w Utah (Digest of education..., 2000: 190). Najbardziej kłopotliwa jest przepaść w osiągnięciach uczniów. Powiększa się ona w miarę upływu lat pobytu w szkole. Szkołę średnią z sukcesem kończy przeciętnie $88 \%$ uczniów.

Większość Amerykanów posyła dzieci do szkoły publicznej, do której zostały przydzielone. Howell i Peterson uważają, że jest to dziwne w porównaniu z naciskiem na wolność wyboru w innych dziedzinach (2002: 5). Moe (2001) twierdzi, iż wielu Amerykanów podziela ideologię szkoły publicznej. Żywią oni długotrwałą, niezmienną wiarę w tę szkołę. Są za rozszerzeniem publicznego sektora oświaty, finansowanego i zarządzanego przez państwo. Integracja uczniów z różnych środowisk była jednym $z$ tradycyjnych celów szkolnictwa publicznego. Ten ideał jest szeroko popierany. Celem jest popieranie równego dostępu do możliwości edukacyjnych i promowanie zdrowych interakcji społecznych wśród uczniów - tolerancji i obywatelskiej otwartości na odmienność, zwiększanie spójności społecznej i redukcja napięć rasowych. Oczywiście są wątpliwości czy te cele zostały osiągnięte. Wybór szkoły może zwiększyć integrację uczniów, gdyby się udało rozbić powiązania między miejscem zamieszkania a ocenami uczniów, gdyby szkoły na przedmieściach były dostępne dla wszystkich i gdyby promowano małe szkoły nie praktykujące podziału uczniów tych samych klas na odrębne ścieżki programo- 
we. Natomiast do pogorszenia integracji będzie prowadziło zwiększanie możliwości wyboru dla rodzin z klas średnich i wyższych, „zbieranie śmietanki” uczniów najzdolniejszych czy bardzo wyspecjalizowane misje szkoły. Polityka pozwalająca szkołom na selekcję uczniów redukuje integrację, a promuje tworzenie szkół dla uczniów z grup ryzyka (Gill, 2005: 132-137).

Respondenci narodowego sondażu Gallupa z roku 2000 ocenili szkoły publiczne na ocenę $\mathrm{C}$ lub gorszą, ale szkołom w ich lokalnej społeczności noty A lub B - w 70\%. Nie mniej niż 87\% rodziców z centrów metropolii jest zadowolonych ze szkoły podstawowej (Tucker, 2005: 168). Na podstawie tych badań Moe stwierdził, że Amerykanie są dość usatysfakcjonowani swoimi lokalnymi szkołami i ta satysfakcja jest zadziwiająco rozpowszechniona w poprzek kontekstów poszczególnych dystryktów szkolnych. Dotyczy to także wielu ludzi w dystryktach upośledzonych, w których szkoły wielu ekspertów uznałoby za nieadekwatne (Moe, 2001: 91). Ale zadaniem filozofów jest zmiana takich laickich opinii o narodowych instytucjach z ich politycznymi tradycjami. Jego zdaniem racjonalność wskazówek Deweya dotyczących szkoły publicznej nie pasuje do liberalnych tradycji zawartych w deklaracji niepodległości. Moe pyta: czy możliwe jest prowadzenie systemu edukacji przez państwo narodowe bez ograniczania procesów nauczania i wychowania, ich społecznych celów, bez przymusu i bez korupcji?

System oświatowy powiększył się i stał się bardziej centralnie kontrolowany. Spowodowało to duże oddalenie szkoły od społeczności lokalnej.

Placówkami z wyboru są szkoły magnet. Inne inicjatywy wyboru były kontrowersyjne i żadna nie została wprowadzona na większą skalę. Vouchery pozostają najbardziej dalekosiężną i najbardziej kontrowersyjną ze wszystkich możliwości wyboru. Przeciwstawiają się im związki zawodowe nauczycieli (Howell, Peterson, 2002: 13). Reforma była dziełem koalicji egzekutyw korporacji i funkcjonariuszy państwa, którzy argumentowali, że kontynuowanie globalnej hegemonii Stanów Zjednoczonych wymaga restrukturyzacji szkolnictwa (Berman, 1999: 259).

\section{Opozycja przeciw voucherom i rynkowym reformom edukacji}

Zwolennicy rynku edukacyjnego używają między innymi argumentu efektywności dla wzmocnienia twierdzenia, że wspierają kluczową wartość - equity - sprawiedliwość społeczną. To pojęcie wiąże się z subiektywnymi sądami moralnymi lub etycznymi. Natomiast pomijane przez nich equality oznacza rzeczywisty wzór, zgodnie z którym coś jest dystrybuowane między członkami poszczególnych grup (Farrell, 1999: 158). Zastosowanie mechanizmów rynkowych - prywatyzacji, decentralizacji oraz innych - by rozwiązać problemy równego dostępu do edukacji, może prowadzić do nieobliczalnych konsekwencji o skutkach odwrotnych (Arno- 
ve, 1999: 10). Dążenie do equity straciło na mocy $w$ latach 90., zostało zastąpione przez dążenie do „adekwatności” (Hanushek, Lindseth, 2009, s, 94).

Koncepcja wyboru publicznego analizuje kwestię wewnętrznej efektywności, konkludując, że wybór i konkurencja stworzą szkołę maksymalizującą osiągnięcia uczniów. Szkoła maksymalizująca rozszerzenie dostępu służy celom egalitarnym (Chubb, Moe, 1990). Maksymalizacja efektywności jest zrównana z maksymalizacją równości. Twierdzenie o promowaniu równości - której niby służą vouchery to jednak ideologiczny trzon i kluczowe uzasadnienie istnienia szkół publicznych (Smith, Meier, 1995: 42).

Chubb i Moe równość możliwości operacjonalizują jako preferencje rodziców. Jest to wszakże ideologiczna przykrywka zawstydzająco ideologicznej agendy skierowanej przeciw szkołom publicznym. Ta ideologia chce raczej zinstytucjonalizować niż zredukować nierówności (Chubb, Moe, 1990: 52).

Zwolennicy wolnego rynku w edukacji uzasadniają swoje reformy twierdzeniem, że pieniądze nie odgrywają w nich roli. W „udowodnianiu” tej tezy główną rolę odgrywa Eric Hanushek. Cytuję niektóre jego konkluzje ze stosunkowo nowej książki, bo z 2009 roku „ Jest mało, albo nie ma wcale, dowodów, że większe nakłady (na szkolnictwo - E. P.) są związane z lepszymi osiągnięciami” (s. 56), „Brak jakichkolwiek stałych relacji między ilością wydatkowanych pieniędzy a osiągnięciami” (s. 68), „Biorąc pod uwagę brak stałych relacji między nakładami i osiągnięciami, nie można przewidzieć, czy znaczne zwiększenie funduszy dla dzieci biednych czy niepełnosprawnych w ogóle da poprawę osiągnięć” (s. 68), „Dostępne dane sugerują, że jest tylko kilka różnic w efektywności pracy nauczycieli kształconych tradycyjnie i tych, którzy dostali się do zawodu alternatywnymi drogami” (s. 82). Zarówno w Stanach Zjednoczonych, jak i w Wielkiej Brytanii coraz chętniej zatrudnia się w szkołach byłych wojskowych czy policjantów. „Istnieją setki studiów i relacji z życia codziennego, pokazujące, że jest mały związek między osiągnięciami uczniów a nakładami finansowymi” (s. 136). Jeżeli nierówność nakładów nie ma wpływu na jakość nauczania, to nierówność dystrybucji zasobów w kraju odgrywa małą rolę w wyrównywaniu możliwości edukacyjnych.

Hanushek dokonał przeglądu 377 studiów dotyczących produkcji edukacyjnej dla poparcia swoich tez. Z tych 377 większość jednak zawierała konkluzje, że istnieje pozytywna i statystycznie istotna zależność między nakładami na szkolnictwo i osiągnięciami uczniów. Twierdzenie, że zależności nie było, znajdowało się w $1 / 3$ z tych studiów. Zatem teza Hanushka opierała się tylko na tej 1/3 studiów (Vestergen, Clark, 1988; Hedges, Laine, Greenwald, 1994).

Inna dostarczycielka „dowodów” na rzecz wolnorynkowych reform edukacji - Caroline Hoxby - oszacowała, że tylko 3\% wariancji osiągnięć uczniów zależało od szkoły (2001: 98).

W przeciwieństwie do tego, co twierdzą Hanushek, Lindseth i Hoxby, coraz więcej badań empirycznych wskazuje na pozytywną korelację nakładów finanso- 
wych i osiągnięć szkolnych. Badania te są zgodne z metodologią produkcji edukacyjnej - na wzór ekonomicznej - i stosuje się w nich analizę regresji, technikę statystyczną, w której inferowana jest zależność od jakości danych. Argument, że pieniądze się nie liczą, jest polityczny (Smith, Meier, 1995: 52-53). Ekonomiczna efektywność rynku postulowana przez Bank Światowy sprowadza się do redukcji wydatków publicznych na jednego ucznia, zwiększenia liczby uczniów przypadających na jednego nauczyciela, nauczania jednym frontem, ekspansji szkolnictwa średniego i wyższego poprzez zwiększanie prywatyzacji i ograniczenia publicznego finansowania do poziomu podstawowego (Carnoy, 1999: 42-43). Kultura rynku coraz bardziej podminowuje instytucje edukacji, starając się zdelegitymizować dyskurs zmagań z nim (Mundy, 2007: 80).

Jonathan Kozol (2005) stwierdza, że nierówności zasobów finansowych reprezentują instytucjonalizację nierówności podklasy ze śródmieść metropolii, biednych, mniejszości. Nierówności finansowe są związane z geografią. Uczniowie biali uczęszczają do dobrze finansowanych szkół znajdujących się na przedmieściach.

Zdaniem Chubba i Moe mechanizm rynkowy będzie korzystny dla wszystkich, bo stworzy lepsze możliwości eukacyjne. Jednak ich teoria jest tendencyjna na rzecz rynku. Ich założenie mówi, że przesunięcie ku rynkowym formom szkolnictwa będzie promowało doskonałość - cel uniwersalnie pożądany (Chubb, Moe, 1990: 82). Tę doskonałość pojmują jako lepsze wyniki w standaryzowanych testach. Te jednak są bardzo krytykowane.

Opozycja w ogóle kwestionuje możliwość uzyskania lepszych efektów nauczania poprzez mechanizm rynku. Nie rozwiąże on problemów braku programów i niewystarczających nakładów. Konieczność płacenia za transport dzieci do szkoły to dla wielu rodziców nadmierny wydatek.

Mary Hatwood Futrell - prezes National Education Association - podniosła filozoficzny argument, że edukacja nie jest konsumpcyjnym dodatkiem, ale główną drogą do demokracji. Kształcenie na wysokim poziomie musi mieć miejsce w każdej szkole publicznej. Argumenty te popierał także prezes drugiego związku zawodowego nauczycieli, Albert Shanker. Miał on wątpliwości, czy prawo konkurencji panujące na rynku może być z sukcesem przeniesione do edukacji, w której nie ma miejsca na motywację biznesową. Mocny głos krytyczny sformułował pedagogiczny think tank Design for Change. Prowadził on dwuletnie badania programu wyborów rodziców w Nowym Jorku, Chicago, Filadelfii i Bostonie. Konkluzje były negatywne dla programu wyboru. Zdaniem badaczy wybór wiąże się z tyloma niebezpieczeństwami, że nie powinien mieć miejsca jako główna strategia poprawy poziomu edukacji. Uczniowie z grup ryzyka byli odrzucani z programu, który stworzył nową formę segregacji opartą na kombinacji rasy, biedy i wcześniejszych osiągnięć uczniów. Wybór staje się nowym, udoskonalonym mechanizmem segregacji uczniów. Ci z niskimi ocenami, z absencją, z problemami w zachowaniu, niepełnosprawni, ze słabą znajomością języka angielskiego w bardzo ograniczonym 
stopniu mogli uczestniczyć w popularnych ofertach szkolnych. Ten system segregacji operuje też w „subtelny” sposób - uczniowie z grup ryzyka czy niepełnosprawni nie byli rekrutowani, ponieważ nie zostali poinformowani o programie. Doradcy zbyt często próbowali tworzyć reputację ich szkół poprzez pozyskanie uczniów z wysokimi ocenami (Moore, Davenport, 1998).

Jeżeli rządy minimalizują swoją rolę w redystrybucji zasobów, to wpływy środowiska rodzinnego na edukację mają tendencję do zwiększania. Wczesne korzyści z kapitału kulturowego rodziny o wysokim statusie z czasem mogą mieć znaczący wpływ na ucznia. W teorii publicznego wyboru wybór jest ważniejszy niż demokracja (Jones, 2000: 39 i 120).

Uwolnienie się od kontroli, do czego tak bardzo dążą zwolennicy reform wolnorynkowych, może spowodować, że szkoły będą dążyły do celów bardzo dalekich od oczekiwanych. Bardzo prawdopodobne jest, że szkoły publiczne będą kształciły w zakresie podstaw, dobrych nawyków pracy, samodyscypliny oraz umiejętności zawodowo-technicznych. Zróżnicowane cele w różnych typach szkół mają mało wspólnego z doskonałością. Te w placówkach publicznych nie wydają się bardziej rozproszone niż w prywatnych. Ponadto jedynym sposobem rozliczania szkół przyjmujących uczniów z voucherami miał być rynek (Fuhrman, 2003: 34). Tymczasem, przyznaje Merrifield, placówki te nie informują podatników, co się w nich dzieje, wymieniając występujące w nich anomalie.

Betts i Loveless twierdzą, że ironią jest, iż jedną z największych korzyści ruchu wyboru szkoły - zróżnicowanie placówek - oponenci ruchu postrzegają jako jego największą słabość (Betts, Loveless 2005: 2).

Szkoły publiczne są postrzegane przez rząd i środowisko pedagogiczne jako efektywne ośrodki wdrażające wartości obywatelskie, prywatne natomiast są skoncentrowane na wdrożeniu kodów moralnych i religijnych. Edukacja rynkowa stwarza niebezpieczeństwo indoktrynacji, „szmuglowania” wartości faworyzowanych przez małe, homogeniczne grupy obywateli. Rynek będzie kształtował postawy uczniów oraz ich predyspozycje behawioralne. Hutton twierdzi, że szkoły odtworzą szczególnie czystą wewnętrznie ideologię rynkową, która pomniejsza wartość i funkcjonowanie agentów oraz instytucji publicznych (Huston, 1995: 310-328). Badania dostarczają argumentów, że im bardziej rynkowa jest organizacja, tym bardziej klasy średnia i wyższa są uprzywilejowane społeczno-ekonomicznie i bardziej predystynowane do osiągania korzyści. Ryzyko związane z reformami rynkowymi jest bardzo wysokie, natomiast ewentualne korzyści niepewne (Smith, Meier, 1995: 112 i 125).

Podstawowy problem ram analitycznych opartych na wartościach rynkowych oraz ich zastosowaniu w edukacji polega na tym, że ukrywana jest „,czarna skrzynka”. Konstrukcja teoretyczna tego rodzaju jak wybór publiczny nigdy nie odpowie, jak żądania są przetransponowane w umiejętności intelektualne czy zdolności poznawcze. Vouchery już „celują” w niższe grupy społeczne. Rynek ma pokonać szkolnictwo publiczne. Politolodzy zwracają szczególną uwagę na reformy rynkowe z punk- 
tu widzenia ich implikacji dla demokracji. Stały się one głównym nurtem polityki, ponieważ apelują do preferencji co do wartości. Jednak ekonomiści nie mogą opracować sensownych priorytetów edukacyjnych oraz strategii. Ignorują oni procesy uczenia się i zadania społeczne. Pomijanie tych aspektów jest systemową przyczyną odpadu szkolnego. Tymczasem Bank Światowy ciągle sugeruje, że wie więcej o edukacji dzięki udoskonalonej i rozszerzonej bazie badań. Wbrew tym twierdzeniom Stany Zjednoczone oferują tylko minimum bezpieczeństwa socjalnego w edukacji (Samoff, 1999: 69 i 83). Neoliberalizm i państwo neoliberalne dążą do drastycznej redukcji sektora publicznego. Jednak odrzucenie wszystkich państwowych programów jest niemożliwe z powodów symbolicznych i praktycznych (Morrow, Torres, 1999: 93-97). Dywersyfikacja szkolnictwa prowadzi do dalszej stratyfikacji, w której mechanizmy zamknięcia są przedefiniowywane i maskowane pod fasadą demokracji i merytokracji, przy dwu przeciwstawnych mechanizmach - leseferyzmu oraz interwencji państwa (Berman, 1999: 297).

\section{Trudności we wprowadzaniu voucherów}

Sąd Najwyższy Stanów Zjednoczonych stwierdził, że vouchery są niezgodne z konstytucją, później jednak zmienił decyzję i stwierdził, iż mogą być zgodne z nią, ale nie jest to dobra polityka oświatowa. Mimo to prezydent George W. Bush nazwał tę drugą decyzję historycznym zwrotem w amerykańskim myśleniu o edukacji. Przyznał jednak, że vouchery to kwestia prawa cywilnego, które nigdy nie zdobędzie poparcia obydwu partii. Opowiedzenie się za nimi dla większości demokratów byłoby politycznym samobójstwem (Moe, 2006: 135). Sąd Najwyższy uznał jednak za niezgodne z konstytucją prawo stanów południowych, które zalegalizowały vouchery pozwalające na przejście do szkół prywatnych dopuszczających segregację rasową. Sędzia Earl Warren stwierdził, że możliwości edukacji muszą być otwarte dla każdego na równych warunkach (Howell, Peterson, 2002: xii i 57).

Wiele stanów miało tak restrykcyjne konstytucje, iż nie zezwalały one na wprowadzenie tej formy prywatyzacji szkolnictwa. Sąd Najwyższy Florydy uznał vouchery za niezgodne z konstytucją (Hanushek, Lindseth, 2009, s, 77). Ponadto, nawet gdy vouchery miały oparcie w konstytucji stanowej, to nie zawsze przezwyciężały opór przeciwko ruchowi wyboru szkoły (Peterson, 2006: 1-9). Spowodował on, że prawnicy opowiadający się za tą formą prywatyzacji edukacji zaczęli szukać alternatywnych sposobów wspierających ruch wyboru szkoły. Jednak propozycje np. nieopodatkowanych kredytów na czesne nie spotkały się ze znacznym poparciem (West, 2006: 159).

Niektóre szkoły prywatne nie chcą uczestniczyć w programie wyboru i przyjmować uczniów z voucherami, ponieważ jest to związane z rozliczeniami i sprawozdawczością (Hassel, 2006: 187). 
Bezspornym liderem oporu przeciwko wprowadzeniu voucherów były związki zawodowe nauczycieli. Zdaniem Moe jest to prawdopodobnie najsilniejsza grupa interesów w Stanach Zjednoczonych (sądzę, że demonizuje on związki i na pewno siła biznesu jest większa). Dla związków zawodowych vouchery są zmorą, bowiem stworzą znacznie mniej regulowany system, nad którym związki będą miały zdecydowanie mniejszą kontrolę. Związkowcy są podejrzliwi wobec rynku, obawiają się, że ta forma prywatyzacji oświaty będzie promowała segregację, obawiają się także o uczniów z rodzin o niskich dochodach. Także interesy własne związków zawodowych prowadzą do przeciwstawiania się tego rodzaju propozycji.

Na wpływy związków zawodowych bardzo wrażliwi są demokraci. Zdaniem Moe, to związki finansują pomoc i kampanie polityczne oraz wyborcze demokratów. Przede wszystkim mają miliony członków, wyborców. Ten gorący zwolennik „wolnego rynku” w edukacji twierdzi, że demokraci „siedzą w kieszeni nauczycielskich związków zawodowych”. Demokraci zajmują wpływowe pozycje we władzach publicznych, mogą być zaliczani do protektorów interesów związków zawodowych. Trudno tę koalicję pokonać. Demokratyczne instytucje mają ogromną liczbę powiązań. Z tego względu wprowadzenie nowego prawa oświatowego jest ogromnie trudne, a jego blokowanie bardzo łatwe.

Prócz związków nauczycielskich przeciwko voucherom protestowały też American Association of School Administrators, National School Boards Association, National Congress of Parents and Teachers, American Civil Liberty, National Urban League oraz związki religijne, a zatem środowiska administratorów szkolnych, rad szkolnych, rodziców i nauczycieli i inne. Obecnie system oświatowy jest ogromnym rezerwuarem pieniędzy, władzy, pracy i wsparcia. Rocznie wydaje 400 miliardów dolarów. Vouchery dotykają wszystkich tych aspektów systemu. Pieniądze i praca pójdą za nimi. Z tego powodu grupy korzystające $\mathrm{z}$ istniejącego systemu postrzegają je jako zagrożenie dla ich najbardziej fundamentalnych interesów. Oponują całą siłą (Moe, 2006: 137-138).

Struktury rządowe popierają opozycję przeciw voucherom, ruch ten ponosi polityczne straty. Postępowanie musi iść drogą małych kroków, rząd stwarza złą perspektywę. W pierwszej dekadzie XXI wieku kwestie voucherów siedem razy poddawano głosowaniu i za każdym razem były odrzucane. Daje to amunicję opozycji. Robert Chase, prezydent National Educational Association, stwierdził, że kolejne porażki voucherów - w Michigan i Kalifornii - powinny położyć kres mitowi, że wyborcy chcą voucherów. Powinny one umrzeć jako zła idea (Moe, 2006: 138-144).

Amerykanie nie chcą rewolucji oświatowej, dążą do utrzymania systemu szkolnictwa publicznego - usprawnionego - i ewentualnie dodania voucherów, jeżeli związane z tym ryzyko dla szkół publicznych będzie minimalne. Myślą, że ich lokalne szkoły są filarem demokracji i zasad egalitarnych. Sądzą również, iż te zasady zasługują na zaangażowanie i wsparcie. Społeczeństwo mało wie o idei voucherów. W roku 1994 „Phi Delta Kappan” stwierdził, że rodzice uczniów szkół prywatnych popierają vouchery przeciw szkołom publicznym w 51\%. 
Moe uznał, że najlepsze, co mogą zrobić liderzy ruchu voucherów, to włożyć całą energię i zasoby w pracę polityczną i wprowadzenie nowej legislacji. Bariery sukcesu nie są zupełnie poza kontrolą. Można poruszać się do politycznego centrum, wysuwać umiarkowane propozycje, z małym ryzykiem i na tej podstawie tworzyć koalicję do zwycięskiej bitwy (Moe 2006: 145-147).

Nowa argumentacja za wprowadzeniem voucherów musi mieć mniej wspólnego z rynkiem, a więcej z równością społeczną. Takie przesłanie ustawi opozycję w wyjątkowo trudnej sytuacji. Spowoduje alians konserwatystów, ludzi o niskich dochodach i ze śródmieść metropolii. Argument równości i małego ryzyka o wiele lepiej apeluje do społeczeństwa niż mantra wolnego rynku. Taki alians zwyciężył w Milwaukee. Podobnie proponuje przezwyciężać opór Lieberman - adresować vouchery do mniejszości, rodziców dzieci niepełnosprawnych i uczniów ze słabymi ocenami (Lieberman, 1986: 196-197).

Moe przewiduje, że polityczna pozycja nauczycielskich związków zawodowych i zdolność blokowania polityki voucherów prawdopodobnie bardzo się pogorszą. Legislacja jest kontrolowana przez republikanów, edukacja specjalna rozszerza możliwości voucherów na dużą ich liczbę, a grupy praw człowieka bardzo popierają edukację dla niepełnosprawnych. Jednak aktualnie uważają one, że rynek nie jest dla biednych (2006: 148-153).

Ruch voucherów zaczęli wspierać prominentni liberałowie: Robert Reich były minister pracy i Andrew Young - były minister zdrowia i edukacji. Postrzegają oni vouchery jako eksperymentalny i sensowny środek pomocy biednym.

Oponenci voucherów zaczynają tracić argumenty intelektualne i moralne, twierdzi Moe. Jednak trudno będzie przekonać większość demokratów i wysokich urzędników, zwrócić ich przeciwko związkom zawodowym nauczycieli. Zmiany mogą trwać całe dekady, nowy system będzie mieszany - publiczny i rynkowy. Wybór szkoły będzie większy, większa konkurencja i prywatyzacja. Najważniejszą rolą rządu jest sprawienie, by siły rynku pracowały na rzecz kluczowych wartości społecznych, szczególnie równości dla poszkodowanych (Moe, 2006: 154-155). Pesymistycznie na przyszłość voucherów patrzy Lieberman podkreślając, że reforma napotyka tak duże kłopoty prawne i polityczne, że nie będzie w pełni efektywna przez wiele lat (1986: 210).

\section{Szkic rozwoju voucherów}

Narodowym laboratorium publicznego finansowania voucherów był stan Milwaukee. Do ich sponsorowania włączyły się korporacje prywatne, przeznaczając na ten cel do 1988 roku 250 milionów dolarów dla ponad 13000 uczniów. Ta wiadomość była nagłaśniana tak bardzo, że i media włączyły się do reformy. Temat znalazł się na pierwszych stronach między innymi z powodu publicznej fascynacji rozwią- 
zaniami rynkowymi w okresie boomu ekonomicznego, niezadowolenia z efektów pracy szkół publicznych, silnego poparcia gubernatorów republikańskich i prawników, a także z powodu chęci wprowadzenia konkurencji do edukacji. Starania bardzo mocno wspierał prezydent George W. Bush, starając się wprowadzić legislację sprzyjającą tej formie prywatyzacji szkolnictwa publicznego. Bush jeszcze jako gubernator stanu Kolorado wyasygnował granty w wysokości 7500 dolarów każdy dla uczniów 12 placówek publicznych na naukę w szkołach prywatnych. Jego działania zastopował prezydent Bill Clinton (Mittang, Connell, 2001: 22).

Do roku 1998/1999 z tej formy pomocy finansowej skorzystało 13000 uczniów. Nowo utworzony Children Scholarship Fund przyznał vouchery dla 40000 dzieci i młodzieży (Moe, 2001: 149). W roku 2001 vouchery otrzymywało 6,1\% uczniów (Merrifield, 2001: 149). W roku 2002 istniało 41 szkół voucherowych, w których 80\% uczniów otrzymało tę formę pomocy. Brak jednak ogólnych danych dotyczących całego kraju, informujących o tym, które kategorie uczniów korzystały z omawianej formy pomocy (Gill, Timpane, Brewer, 2001: xv). Także dane fragmentaryczne są nieliczne. W Milwaukee vouchery przyznano dzieciom rodziców o niskich dochodach - w roku 1990 w 1103 szkołach (Belfield, Levin, 2005: 25). Według Howella i Petersona omawianą formę prywatyzacji popierało $67 \%$ rodziców tej kategorii. Sami jednak piszą, że tylko 29\% rodziców o niskim statusie społeczno-ekonomicznym skorzystało z oferowanych voucherów (Howell, Peterson, 2002: 27 i47). Prezydent George W. Bush ogłosił, że tego rodzaju pomoc otrzyma 1200 uczniów z biednych rodzin. Jak zwykle było to działanie symboliczne, stwierdził Campbell (2006: 228).

W 1999 roku 14\% uczniów z sektora publicznego uczęszczało do szkół wybranych przez rodziców (Betts, Loveless, 2005: 12). W 2000 roku liczba voucherów wynosiła 60000 (Howell, Peterson, 2002: 32). Na Florydzie każdy uczeń, który otrzymał ocenę $\mathrm{F}$ (nie zdał) dwa razy w ciągu czterech lat, miał prawo do vouchera w wysokości 4000 dolarów. Otrzymało je 57 osób (Gill, Timpane, Brewer, 2001: 2). W Ohio vouchery EdChoice dla uczniów ciągle mających niskie osiągnięcia w roku 2006 uzyskało 2193 osób, a w roku 2007/2008 - 6800. Był to program zaprojektowany przy chronicznym niedostatku funduszy - stwierdził Matthew Carr w czasopiśmie radykalnie konserwatywnym „The Cato Journal” (2011: 265). Przytoczone liczby świadczą o tym, że skala reformy voucherów była niewielka, biorąc pod uwagę wielkość kraju, jakim są Stany Zjednoczone.

\section{Między deklaracjami a celami rzeczywiście realizowanymi}

Jednym z kluczowych celów ruchu voucherów było generowanie dowodów, które wpłynęłyby na politykę publiczną. Od początku tej fali reform toczy się gra o gromadzenie danych przydatnych do wykorzystania w charakterze silnej broni 
w politycznych zmaganiach ruchu wyboru szkoły. W nowej polityce oświatowej „konserwatyści stali się progresywistami wiążąc się z osobami biednymi. Z kolei progresywiści stali się konserwatystami, broniąc swojego statusu przeciw naciskom zewnętrznym. Jest to konserwatywny rys amerykańskiego systemu edukacji”. Ruch zwolenników voucherów, tworząc nową politykę oświatową, był zarazem główną siłą jej ekspansji, prawdopodobnie najważniejszą polityczną transformacją czasów modernizmu - twierdzi Terry Moe, gorący zwolennik prywatyzacji sektora edukacji publicznej (Moe 2001: 100 i 122).

Ciągle bardzo mało jest jeszcze badań dotyczących skutków wprowadzenia voucherów. Do roku 2001 nie było w ogóle takich badań (Natriello, 2001: 275). Istniejące studia pióra Colemana, Chubba, Moe, Hoxby i wielu innych zwolenników wolnego rynku w szkolnictwie są stronnicze, wybiórczo selekcjonują dane, pomijają dane istotne oraz mają braki w zakresie wewnętrznej trafności konkluzji i w zakresie trafności zewnętrznej - przenoszenia konkluzji z danego studium na szerszy kontekst polityczny (Myers, 2001: 305-313). Pierwszą próbą podsumowania najwcześniejszych badań dotyczących skutków voucherów jest książka Briana Gilla, Michaela Timpanea i Dominica Brewera Rhetoric versus reality. What we know and what we need to know about vouchers and charters (Retoryka a rzeczywistość. Co wiemy i co powinniśmy wiedzieć o voucherach i czarterach, 2001). Ma ona dobre ramy teoretyczne i zrównoważone perspektywy - co jest rzadkością. Wyczerpująco i krytycznie autorzy kontrolowali dane i przeprowadzili nietendencyjny sondaż. Dokonali oni krytycznej analizy teoretycznych podstaw reformy. Tam, gdzie to możliwe, porównywali szkoły publiczne i prywatne.

Książka jest częścią szeroko zakrojonych badań RAND dotyczących reform edukacji w Stanach Zjednoczonych. RAND deklaruje, że jego misją jest poprawne zbieranie danych oraz ich ostrożne i obiektywne przeanalizowanie dla potrzeb narodowej debaty oświatowej (Hill, 2001: III). Lista tego, co już wiadomo, jest bardzo krótka, znacznie dłuższa jest lista tego, czego jeszcze nie zbadano. Prawie wszystkie dane empiryczne pochodziły z małej skali.

Kto korzystał z voucherów? Gill, Timpane i Brewer stwierdzili, że przede wszystkim uczniowie z rodzin reprezentujących klasy średnie i wyższe. Ich dzieci uczyły się w szkołach katolickich mających renomę najlepszych w kraju (poza elitarnymi) (Hess, Loveless, 2005: 95). Swiadczy to o obłudzie zwolenników tej formy pomocy, na pewno doskonale zdających sobie sprawę z tego, że rodziców o niskich dochodach nie będzie stać na pokrycie 50\% kosztów kształcenia ich dzieci w szkołach prywatnych - stwierdzają autorzy z RAND (Gill, Timpane, Brewer, 2001: XV). To było przyczyną wykorzystania oferty voucherów tylko przez $29 \%$ rodziców z tej kategorii. Ascher, Fruchter i Berne (1996: 40-41) twierdzą wszakże, iż rodzice o niskich dochodach "nie są naturalnymi konsumentami edukacji”. Z czasem liczba niewykorzystanych voucherów rosła, uczniowie, którym je oferowano, pozostawali w szkołach publicznych. Najważniejszym powodem rezygnacji była 
niemożność opłacenia/dopłacenia do kwoty przyznanej w voucherze. Najczęściej tę formę pomocy wykorzystywały rodziny białe (Howell, Peterson, 2002: 36-49 i 72). Za niewykorzystywanie voucherów próbuje się oskarżać rodziców. Pisze się, że niewiele rodzin, do których zaadresowane są propozycje voucherów, chce pozyskać informacje konieczne do aktywnego wyboru szkoły. Nie wszyscy rodzice muszą dokonywać tego wyboru. Z drugiej strony, wystarczy, aby tylko część rodziców była poinformowana, aby zaistniał efektywny rynek edukacyjny (Schneider, 1998: 782). John Merrifield stwierdził, że założenie, iż tylko dzieci z rodzin o niskich dochodach potrzebują pomocy, było błędne (2001: 69). Jeżeli jednak główną przeszkodą uzyskania dobrych ocen przez dzieci biedne jest niski dochód rodziców, ich słabe wykształcenie, brak zainteresowania uczeniem się potomstwa czy brak dyscypliny, to absurdem jest myślenie, że ci rodzice staną się wymagającymi konsumentami edukacji (Lemann, 1991: 104).

Hamilton i Guin stwierdzają, że dotychczasowe badania dostarczają dowodu wspierającego jedno z kluczowych założeń modelu wyboru szkoły, mianowicie że rodzice będą wybierać na podstawie jakości edukacji. Jednak rodzice o wyższym statusie społeczno-ekonomicznym z jednej strony i ze statusem niskim oraz z mniejszości podkreślają inny zestaw wartości edukacyjnych przy wyborze. Ponadto biali najpierw eliminowali szkoły z większością uczniów afroamerykańskich i byli mniej zainteresowani ocenami z testów. Rodziców o niskim statusie bardziej interesowało nauczanie „podstaw”, zwłaszcza matematyki i czytania, ponieważ ich zdaniem są one konieczne przy ubieganiu się o przyjęcie na studia i dla sukcesu w życiu, byli też zainteresowani rezultatami testów i bezpieczeństwem w szkole. Niewątpliwie rasa biała i rodziny z wyższym statusem społeczno-ekonomicznym mogły wynieść większe korzyści z rynku edukacyjnego (Howell, Peterson, 2002: 59).

Dla rodzin afroamerykańskich rasa nie ma znaczenia, ale niektórzy mieszkańcy metropolii wybierali pozostawanie w szkole „czarnej”, ponieważ była im znana. Dotyczyło to również niektórych rodziców. Biedę w szkole brano pod uwagę w umiarkowanym stopniu. Rodzice wybierający szkoły mieli wyższe wykształcenie niż niewybierający (Hamilton, Guin, 2005: 42-47).

Wspólna szkoła, do której uczęszczają wszystkie dzieci, jest mitem - konkludują William Howell i Paul Peterson (2002: 58). Segregacja rasowa pozostaje jednym z najważniejszych problemów społecznych w Stanach Zjednoczonych. Sytuacja nie poprawiła się od lat 70., a na południu pogorszyła się. Jim Hunt - gubernator Północnej Karoliny - stwierdził, że vouchery tworzą oddzielny, nierówny system. David Berliner z kolei uważał, iż stanowią one nowy system segregacji obywateli, tym razem używając do tego celu pieniędzy publicznych (Howell, Peterson, 2002: 127-128). Rodzice mogą mieć „wolny wybór” w teorii, ale nie w praktyce. Zyski z tego wyboru na rynku będą bardzo ograniczone - do niektórych grup. Stratyfikacja społeczna na skutek „wyboru publicznego” powiększa się. Rodzice wybierają 
dla swoich dzieci takich samych rówieśników. Efekt segregujący voucherów może być najpoważniejszym zarzutem pod adresem tej reformy (Belfield, Levin, 2005: 43-51).

Problemem jest to, że w rzeczywistości to szkoły, a nie rodzice wybierają. Prywatyzacja, której elementem są vouchery, nasila segregację według ras i klas (Kahlenberg, 2000: 4). Jeżeli nagrody są oczywiste, wówczas szkoły mające wybór będą poszukiwały uczniów zdolnych, zmotywowanych do nauki, z klasy średniej (Brighouse, 2000: 169). Problem tak zwanego „zbierania śmietanki” dotyczy przede wszystkim właśnie szkół prywatnych. Przyjęci uczniowie ze słabymi ocenami bywają wyrzucani. Reputacja placówek prywatnych po części zależy od pozyskania zdolnych uczniów z majętnych rodzin. Waga problemu zależy od specyficznych cech szkoły. Jeżeli vouchery będą dostępne tylko dla uczniów z rodzin o niskich dochodach i jeżeli szkoły odpowiedzą na żądania rodziców, to problem może być mniej poważny (Howell, Peterson, 2002: 20). Całkiem świadomie zakładano, że placówki z nadmiarem uczniów będą stosowały praktyki dyskryminacyjne przy ich doborze (Tough choices ..., 2007: 16).

Programy wyboru szkoły funkcjonują też w taki sposób, że albo bezpośrednio, albo pośrednio wykluczają uczniów z niepełnosprawnościami. Ich edukacja jest kosztowna. Jeżeli szkoła będzie dobrze pracowała z nimi, to zostanie „zalana” dziećmi z tej kategorii (Rothstein, 1999: 357). System oparty na wyborze releguje Afroamerykanów, Latynosów, uczniów z rodzin o niskich dochodach. Szkoły prywatne mogą odmówić przyjęcia uczniów biednych. Po przyjęciu uczniowie ze słabymi ocenami bywają skreślani z listy, a niepełnosprawni zachęcani do odejścia (Levin, 1998: 379). Z kolei dla Howella i Petersona zaskakujące było to, że szkoły prywatne nie wykluczały uczniów z trudnościami w uczeniu się. Uważają oni, iż nie wydaje się, aby vouchery znacząco zwiększyły selekcję w systemie edukacji. Obserwowali umiarkowane selekcjonowanie najzdolniejszych uczniów. Większość Amerykanów akceptuje „zbieranie śmietanki” uczniów jako życiowy fakt. Proces ten przenika cały system edukacji - obydwa sektory. Im bardziej szkoła jest selektywna, tym ma wyższą rangę. Jednak placówki selekcjonujące uczniów według zdolności są wyjątkiem. 85\% szkół publicznych to szkoły sąsiedzkie, do których uczniowie są przypisani z racji miejsca zamieszkania (Howell, Peterson, 2002: 57 i 80-84).

Szkoły przyjmujące uczniów z voucherami miały respektować stanowe wytyczne dotyczące przyjęć. Jednakże, jak konkludują Ronald Corvin i Joseph Schneider, jeszcze bardziej krzywdzą uczniów z rodzin o niskich dochodach, z mniejszości oraz z niepełnosprawnościami w społeczeństwie nieopiekuńczym. Żyjemy w społeczeństwie enklaw, coraz bardziej posegregowani. Retoryczny zwrot „oddzielni, ale równi” zaczyna znowu brzmieć poprawnie (Corvin, Schneider, 2005: 200). Vouchery segregują uczniów, erodują podstawy demokracji (Levin, 1998: 382). Rozwijają one pogląd na świat i zróżnicowany system wartości jako „nasz w przeciwieństwie do ich" (Peterson, 2006: 154). 
Jednak, zdaniem Tuckera, vouchery nie nasilają izolacji rasowej, a szkoły prywatne wzmagają respekt dla praw innych (2005: 139).

Wiele badań ukazuje, że rodzice są bardziej zadowoleni ze szkół prywatnych niż z publicznych. Raport z sondażu ministerstwa edukacji z roku 1999 podaje następujące dane: 78\% rodziców jest usatysfakcjonowanych ze szkół prywatnych, $62 \%$ z wybranych szkół publicznych i $48 \%$ z publicznych, do których zostali przypisani (Digest of... 2000, 2001: 34). Większość rodziców z przyznanym voucherami wykorzystuje je w placówkach katolickich (Murphy, Nelson, Rosenberg, 1997: 10). Uczniowie są mniej entuzjastycznie nastawieni do zmiany szkoły na przyjmującą tych z voucherami, niż rodzice (Tucker, 2005: 176).

Jeżeli chodzi o badanie osiągnięć uczniów $\mathrm{z}$ voucherami i porównywanie ich z rówieśnikami ze szkół publicznych, to poważnym błędem metodologicznym doniesień z badań jest poprzestawanie na obliczeniach średnich statystycznych. Ponadto techniki analiz statystycznych są stosowane, by więcej maskować niż ujawniać, ponieważ zbyt wiele jest wariantów programów i zbyt duże zróżnicowanie uczniów, by formułować rozsądne generalizacje. Standaryzowane testy nie są odpowiednie do formułowania wniosków, że w szkołach, do których przeszli uczniowie z voucherami, poprawiono ich osiągnięcia (Corvin, Schneider, 2005: XXI, 18 i 21$)$.

Z powodów etycznych i politycznych programy edukacyjne rzadko są oceniane przy zastosowaniu randomizowanych badań eksperymentalnych. Gill, Timpane i Brewer poddali analizie badania trwające dłużej, nieeksperymentalne, które wydawały się nietendencyjne. Na ogół nie podlegały one akademickiej ocenie kolegów. Nie było też badań niezadowolenia rodziców z voucherów (Gill, Timpane, Brewer, 2001: 74-75 i 136-137).

Wyraźnym przykładem tendencyjnych „badañ” i błędów wymienionych powyżej są prace Caroline Hoxby, wspomnianej już profesor ekonomii z Harvardu. Hoxby pisze, że jej badania dowodzą, iż w metropoliach z maksymalnym wyborem - w tym dzięki voucherom - uczniowie mieli wyższe oceny z testów w klasach VIII. W dystryktach $\mathrm{z}$ wysoką konkurencją między szkołami wydawano na edukację mniej niż w dystryktach bez konkurencji. Konkurencja podwyższa osiągnięcia uczniów i obniża koszty edukacji. Jej badania pokazały, iż wszystkie szkoły mają wyższe osiągnięcia tam, gdzie jest ostra konkurencja między szkołami prywatnymi i publicznymi. Inne studia - zdaniem Hoxby - wykazują znacznie lepsze osiągnięcia uczniów szkół prywatnych. Wprowadzenie voucherów w Milwaukee, konkurencja $\mathrm{z}$ nimi związana, poprawiła osiągnięcia w klasach $\mathrm{z}$ uczniami o niskim statusie społeczno-ekonomicznym ich rodziców oraz uczniów z mniejszości. Jej zdaniem, zaprezentowane wyniki wykazują stały wpływ konkurencji na podwyższanie osiągnięć szkolnych. Szkoły amerykańskie mogą mieć oceny o $28 \%$ wyższe (Hobby, 2006: 195-203). Również Paul Peterson - zwolennik voucherów - doszedł do konkluzji, że miały one pozytywny wpływ na oceny uczniów. Jego publikacja 
z roku 1996 wywołała niemało kontrowersji. Belfield i Levin z kolei - po przeanalizowaniu studiów dotyczących tego problemu - stwierdzili, że ewentualny wpływ był bardzo słaby, nieistotny statystycznie (Belfield, Levin, 2005: 129-141).

Wracając do Hoxby - powołując się na studia z podobnymi wnioskami, nie pisze, które to studia. Nie dokumentuje także swoich badań i tez. W ogóle nie przedstawia metodologii swoich badań - jak na przykład orzekała o większym lub mniejszym wyborze szkół, o ostrzejszej lub mniej ostrej konkurencji, czy jak porównywała wydatki szkół prywatnych i publicznych. Na jakiej podstawie oszacowała, że szkoły amerykańskie mogą mieć osiągnięcia o $28 \%$ wyższe? Bardzo dużo do życzenia pozostawiają jej przypisy. Z powodu wielu poważnych braków metodologicznych „konkluzji” Hoxby nie można uznać za wiarygodne. Podobne braki metodologiczne charakteryzują różne rozdziały książki pod redakcją Paula Petersona Choice and competition in American education (Wybór i konkurencja w edukacji amerykańskiej).

Badania empiryczne dotyczące voucherów koncentrują się na ocenach uczniów, często ignorując inne kluczowe dymensje. Ponadto ograniczają się przede wszystkim do korzystających z tej formy pomocy, a nie uwzględniają ich rówieśników ze szkół publicznych - z wyjątkiem nielicznych grup kontrolnych (Hill, 2001: XXII).

Ewaluację osiągnięć szkół w Milwaukee przeprowadzili Cecilia Rouse (1998) i John Witte (2000) - ewaluator powołany przez stan. Specjalny raport przygotowany pod jego kierunkiem przez badaczy z Uniwersytetu Princeton zawiera wniosek, iż Milwaukee poniosło porażkę w udowodnieniu, że vouchery udoskonaliły szkoły. Obydwoje z Rouse stwierdzili, że nie było różnic w osiągnięciach uczniów z voucherami oraz ich rówieśników z placówek publicznych. Do roku 2001 jedynie ten program trwał dość długo, by można było wyprowadzać lepiej ugruntowane wnioski. Po roku 1995 szkoły przyjmujące uczniów z voucherami nie musiały raportować wyników uzyskanych przez uczniów w testach, nie można więc było przeprowadzać podobnych analiz (Belfield, Levin, 2005: 25). W ogóle bardzo trudno znaleźć dane dotyczące porównania osiągnięć szkół publicznych i prywatnych. Ponadto statystyki nie ujawniają faktu, że wiele placówek publicznych jest tak dobrych, jak prywatne (Corwin, Schneider, 2005: 32). Są one zdolne do reagowania na presje zewnętrzne (Gill, Timpane, Brewer, 2001: 107-109).

Belfield i Levin podkreślają, że vouchery są różne pod względem finansowania, regulacji czy wsparcia stanowego lub jego braku. Planowano je dla umożliwienia wyboru szkoły albo dla bardziej efektywnej produkcji, czy dla większej równości i spójności. W związku z tym różne są też rezultaty. Friedman zwracał uwagę na to, że jeżeli ta forma pomocy zostanie zaplanowana w celu umożliwienia wyboru szkoły oraz efektywnej produkcji, to odbędzie się to kosztem równości i spójności - i odwrotnie (Belfield, Levin, 2005: 40). Niemniej jednak badacze ci stwierdzają, że wprowadzenie voucherów nie przyniosło efektów. Dane z tego rodzaju eksperymentów pokazują słabe osiągnięcia uczniów po trzech latach, osiągnięcia te nie 
poprawiły się (Howell, Peterson, 2002). Frederick Hess i Tom Loveless argumentowali jednak, że żadne systematyczne badania nie zaprzeczyły, iż poprawa nastąpiła (2005: 85).

Najmniej rozpoznane są osiągnięcia poszczególnych, docelowych grupuczniów. Istniejące dane sugerują możliwość, ale nie pewność, umiarkowanej poprawy uczniów afroamerykańskich po jednym lub dwóch latach nauki w szkole prywatnej. Nie wiadomo jednak, co sprawiło tę prawdopodobną poprawę (Gill, Timpane, Brewer, 2001: XII, Tucker, 2005: 166). Howell i Peterson piszą o pozytywnym i statystycznie istotnym wpływie voucherów na oceny uczniów afroamerykańskich. Ich rodzice byli bardziej usatysfakcjonowani szkołą prywatną niż publiczną. Autorzy zaznaczają jednak, że badania miały ograniczony zakres (2002: XXIV-XXV). W roku 2000 pojawiły się informacje, że 75\% uczniów afroamerykańskich i 60\% białych poprawiło swoje oceny po uzyskaniu voucherów. Nie wiadomo jednak, na jakiej podstawie sformułowano tę konkluzję (Grossman, 2003: 90). Tucker - też nie wiadomo, na jakiej podstawie - twierdzi, że vouchery nie mają wpływu na oceny uczniów białych, ale mają w przypadku Afroamerykanów. Ich przejście ze szkół śródmiejskich w metropoliach do prywatnych zmienia ich doświadczenia na wiele ważnych sposobów. Uczą się w mniejszych szkołach, mniejszych klasach, bardziej bezpiecznych. Szkoły prywatne nie mają jednak sukcesów w zmniejszaniu przepaści w ocenach testowych. Ponadto w klasach VI, VIII i starszych są one bardziej dyskryminacyjne (Tucker, 2005: 193 i 215-218). Coleman, Hoffer, Greeley, Wilms i Jencks w swoich esejach w „Sociology of Education” z roku 1985 zgodnie jednak twierdzą, że pomagają one zmniejszać przepaść między grupami etnicznymi (za: Tucker, 2005: 143). Podobnego zdania jest Tucker w odniesieniu do voucherów. Jego zdaniem miały one raczej pozytywny niż negatywny wpływ na izolację etniczną i konflikty (s. 127-130).

Moe powołuje się na sondaż Gallupa z roku 1992, w którym vouchery poparło 71\% Amerykanów, w tym 88\% Afroamerykanów i 84\% Latynosów. Twierdzi też, że największe sukcesy ta forma prywatyzacji odniosła w środowiskach centrów metropolii, ludności kolorowej oraz o niskich dochodach (2001: 71). Moe nie dokumentuje wszakże swoich twierdzeń, powołuje się natomiast na zdanie ekonomistów, którzy sądzą, że satysfakcja klientów jest najlepszą miarą jakości szkoły. Przytacza dane z sondażu narodowej próby rodziców dotyczące oceny wybranych przez nich szkół w skali od A do F. Rodzice z placówek prywatnych najczęściej dawali im ocenę B - w 41\%. Rodzice o niskich dochodach taką samą ocenę przypisali $42 \%$ szkół publicznych i 52\% prywatnych. Autor - profesor ekonomii z Uniwersytetu Stanford - nie podaje jednak wielkości badanej próby rodziców. Howell i Peterson donosili, że vouchery popierało 57\% rodziców uczniów afroamerykańskich (2002: 27). W tym miejscu trzeba zaznaczyć, iż nie ma badań niezadowolenia rodziców z voucherów. Ponadto Belfield i Levin zwracają uwagę na fakt, iż pozytywne osiągnięcia uczniów afroamerykańskich są kwestionowane ze względu na braki me- 
todologiczne badań dotyczących tej kwestii. W ogóle bardzo częstą przypadłością rzeczników voucherów jest to, że nie podają źródeł danych, które przytaczają (Gill, Timpane, Brewer, 2001: 27-28). Po analizie różnych badań konkluzja Gilla, Timpane i Brewera brzmi: nie ma zgodności wniosków w sprawie poprawy osiągnięć uczniów korzystających z voucherów. Zwolennicy tej formy prywatyzacji twierdzą, że spowodowała ona podwyższenie wyników uczniów. Nie wyjaśniono, dlaczego oceny są takie, a nie inne. Howell i Peterson zwracają uwagę na fakt, że przepaść w osiągnięciach uczniów z różnych grup rasowych, etnicznych, statusu społecznoekonomicznego rodziców to najbardziej kłopotliwa sprawa amerykańskiej edukacji. Dzieci rodziców wykształconych zawsze mają lepsze osiągnięcia niż te z mniej uprzywilejowanych środowisk (Howell, Peterson 2002: 3). Tucker donosi jednak, że vouchery spowodowały zmniejszenie nierówności w ocenach uczniów w 6 z 8 porównań - także w przypadku uczniów, którzy nie otrzymali tej formy pomocy. Jednak jego konkluzja jest ostrożniejsza: wyniki ani nie potwierdzają ostrzeżeń, ani obietnic, że vouchery stopniowo wyeliminują nierówności w ocenach z testów (Tucker, 2005: 158-166).

Ciekawy jest fakt, że 40\% uczniów z voucherami wróciło do szkół publicznych w ciągu 3 lat, 7\% odpadło, ale później wróciło do szkoły prywatnej (Tucker, 2005: 13). Nie wszyscy rodzice uważali, że wybrana szkoła była korzystna dla ich dzieci (Howell, Peterson, 2002: 83).

Czy zebrane dane potwierdzają twierdzenie Caroline Hoxby, że wszystkie szkoły mają lepsze osiągnięcia tam, gdzie ma miejsce ostra konkurencja między nimi oraz że wpływ konkurencji jest stały? Relacjonowałam już ogromne metodologiczne zastrzeżenia dotyczące jej badań. W przeciwieństwie do niej Smith i Meyer stwierdzili, że występuje negatywna korelacja między konkurencją w sektorze prywatnym a wynikami uczniów osiągniętymi w standaryzowanych testach. Nie ma jasnych dowodów, iż konkurencja ze strony szkół prywatnych podwyższa osiągnięcia w testach uczniów placówek publicznych. W „badaniach" zwolenników voucherów - do których należy Hoxby - nie ma danych dotyczących wyjaśnienia zaistniałej sytuacji, tylko mnóstwo spekulacji (Smith, Meyer, 2005: 40).

Badania dotyczące wpływu różnych form edukacji prywatnej i konkurencji są kwestionowane. Nikt nie może być pewien, jakie są edukacyjne konsekwencje poważnych przesunięć na rynku szkolnym. Jeżeli dane empiryczne nie dają odpowiedzi na pytania o rezultaty voucherów, to dlaczego ich obrońcy bronią ich $\mathrm{z}$ taką pasją, a oponenci atakują? Belfield i Levin sądzą, że aspekt ideologiczny reformy ma większy wpływ niż jej efekty. Dla zwolenników „wyboru publicznego" wybór jest najważniejszym priorytetem. Dla oponentów edukacja jest częścią kontraktu społecznego a szkoły publiczne wpływają na spójność i równość $\mathrm{w}$ narodzie. $\mathrm{Z}$ kolei biznes z coraz większą siłą dąży do potencjalnych zysków (Belfield, Levin, 2005: 56-57). 


\section{Prognozy dołyczace przyszłości voucherów}

Henry Levin nie spodziewał się lepszych efektów uczniów z voucherami (2006: 27). Nawet gorący zwolennik tej formy prywatyzacji - John Merrifield - twierdził, że niepowodzenia analizowanej reformy należy przypisać nierealnym oczekiwaniom wobec niej. Obietnice obrońców tego ruchu nie spełniają się i nie spełnią (Merrifield, 2001: 28). Do takiego samego wniosku doszli Corwin i Schneider po ponad 10 latach badań i obserwacji (Corwin, Schneider, 2005: 18). Nawet Lieberman stwierdził, iż bardzo mało było bezpośrednich dowodów, że reforma voucherów poprawi stan edukacji (1996: 198). „Phi Delta Kappan” wskazało na spadek poparcia dla niej. Prostota idei voucherów jest myląca. Jeżeli idea zostanie szeroko i powszechnie zastosowana, to będzie zdolna do transformacji całego systemu szkolnego. Dlatego wzbudza taki opór (Moe, 2006: 135-137). Polityczne napięcia pomiędzy zwolennikami i przeciwnikami wyboru szkoły pogłębiają się. Pracujący w tym ruchu doznają wielu niepewności: prawnych, w zakresie regulacji i finansowych (Betts, Loveless, 2005: 11; Gill, 2005: 83).

Tucker stwierdza, że nowe szkoły w biednym społeczeństwie zostaną otwarte tylko wtedy, kiedy rządowa polityka spowoduje finansowe zachęty do ich otwarcia. Szkoły z voucherami powinny otrzymywać takie same kwoty na jednego ucznia, jak placówki czarterowe i publiczne; na ucznia niepełnosprawnego więcej. Koszty kapitałowe powinny być pokrywane przez rząd. Tylko wtedy wszystkie szkoły będą miały zapewnione ten sam poziom wsparcia publicznego. Tylko wtedy zaistnieją zachęty do podejmowania ryzyka tworzenia nowych szkół. Jest to głos prezesa Narodowego Centrum Edukacji i Ekonomii (Tucker, 2005: 195).

Mobilizacja sił przeciwnych koncepcji wyboru publicznego związana jest z czymś więcej niż z refleksyjną ideologią czy interesem własnym. Henig sugeruje odmienne teorie o naturze rządu, polityki, zmiany politycznej dzielące zwolenników i adwersarzy voucherów. On sam wskazuje na różnicę między prywatyzacją pragmatyczną i systemową. Ta pragmatyczna jest selektywna i dotyczy doskonałego dopasowania odpowiedzialności publicznej i prywatnej celem maksymalizacji kolektywnego dobra. Nie pomniejsza ona kluczowych możliwości instytucji publicznych. Prywatyzacja systemowa znacząco reorganizuje władze publiczne i prywatne siłami politycznymi, ideologicznymi, instytucjonalnymi, które mogą się wymknąć kontroli publicznej.

Brookings Commission on Choice in K-12 Education - Komisja ds Wyboru w Edukacji - zwracała uwagę na różne typy wyborów, na różny ich kontekst, na to że redukcja kosztów kształcenia w programach wyborów nie jest prawdopodobna, a nawet potrzebne są dodatkowe nakłady, że wybory nie będą projektowane politycznie i nie będą miały wstępnych intencji. W ogóle ruch ku rynkowi, wyborowi szkoły i prywatyzacji dostarczania edukacji nie jest ruchem rewolucyjnym, stwierdza Henig (2005: 177-178 i 183). Stany Zjednoczone są doskonałym przykładem 
tego, że wysiłki prywatyzacji - przez contracting - out, deregulację i vouchery pojawiły się jako pragmatyczne wysiłki zmuszające rząd do lepszej pracy w realizowaniu szerokiego zakresu odpowiedzialności publicznej. Prywatyzacja edukacji niekoniecznie jest niespójna $\mathrm{z}$ demokratycznym rozliczaniem.

Rynkowa organizacja edukacji obejmie co najmniej dostarczanie jej, regulację i podejmowanie decyzji. Prywatyzacja szkolnictwa tworzy system wyjątkowo zróżnicowany.

Silna opozycja polityczna kwestionuje zgodność voucherów z konstytucją i spowodowała, że reforma związana $\mathrm{z}$ tą formą prywatyzacji szkolnictwa ma zasięg ograniczony i charakter eksperymentalny, zniechęcający do inwestycji. Senat stanu Wisconsin obciął fundusze na vouchery i ustalił dodatkowe restrykcje. Finansowanie przywrócili republikanie. Kontrowersje związane z voucherami ujawniły wiele niebezpieczeństw politycznych. Tymczasem zmiana systemowa nie zmaterializuje się przy małej liczbie voucherów - ubolewa Tucker (2004: s. 197).

Program na wielką skalę może być atrakcyjny dla 10\%-15\% uczniów szkół publicznych, ale nie na tyle, by spowodował ich masowy exodus do placówek prywatnych i tym samym „spowodować głód uczniów” w sektorze publicznym bez możliwości zareagowania na tę sytuację. Z czasem programy wyboru szkoły spowodują większe modyfikacje w placówkach publicznych, ale zmiany będą następowały powoli.

Vouchery nie zmienią nakładów na edukację - konkluduje dalej Tucker - tylko ich dystrybucję. Opozycja twierdzi, że drenują one pieniądze z sektora publicznego do prywatnego. Autor uważa, iż same vouchery nie dokonują takiego drenażu, ale wszystkie możliwości wyboru szkoły razem - tak, przyznaje Tucker (2004: s. 200-202).

Nawet uniwersalne programy voucherów nie przekroczą możliwości finansowych państwa. Jednak w sektorze publicznym zmiana jednej formy organizacyjnej w szkolnictwie na inną narzuca bardzo widoczne i politycznie ryzykowne koszty krótkoterminowe. Zwiększenie finansowania voucherów będzie politycznie trudne do osiągnięcia (Betts, Goldhaber, Rosenstock, 2005: 61). W obecnym klimacie politycznym szanse istnienia mają trzy typy voucherów: dla uczniów ze szkół „upadających”, z rodzin o niskich dochodach oraz dla uczniów ze śródmieść metropolii. Jeżeli ta forma prywatyzacji szkolnictwa ma odnieść sukces polityczny, to musi obrać za swój cel obszary, na których niezadowolenie z placówek publicznych jest największe (Tucker, 2004: 207). Dla Erica Hanushka największym problemem jest to, że w ogóle przestano choćby rozważać takie propozycje reform, jak vouchery. Tymczasem było dla nich znaczne poparcie przed negatywną kampanią przeciwko nim. Opozycja nadal jest silna (Hanushek, 2009: 183-184, 233, 279). Społeczeństwo żąda też ścisłego regulowania „szkół wyboru” finansowanych z pieniędzy publicznych. Ale jeżeli szkoły te są efektywne dzięki możliwości wykluczania uczniów sprawiających kłopoty i dzię- 
ki dyscyplinie, to odebranie im tej możliwości będzie polityką nieproduktywną (Betts, Loveless, 2005: 95-98).

Henig reprezentuje ostrożny optymizm co do pragmatycznej prywatyzacji dostarczania edukacji. Jego zdaniem siły przeciwników nie są wystarczające, by ją zatrzymać. Pragmatyczna prywatyzacja zwycięży, jeżeli polityka publiczna zostanie zmobilizowana przez elity. Istniejący już system mieszany odzwierciedla kruchy kompromis. Ale utworzenie, utrzymanie i mobilizacja „koniecznej koalicji rozumnych" to trudna praca (Henig, 2005: 201).

\section{Podsumowanie}

Populizm i obłuda zwolenników reformy „wyboru rodziców” z jednej strony, tendencyjne zbieranie „danych”, ale i mówienie wprost, o co chodzi w ruchu voucherów - jak choćby przez Tuckera - świadczą o tym, że idea publicznego wyboru to nie teoria, lecz ideologia.

Ruch zwolenników voucherów to najbardziej upolityczniona i urynkowiona reforma edukacji amerykańskiej od czasów administracji Reagana. Bardzo wyraźne było dyrygowanie nim przez neoliberałów. Dobitnym przykładem jest fundacja Friedmanów, mająca za cel zalegalizowanie tej formy prywatyzacji szkolnictwa. Reforma zaczęła się od zwiększenia publicznego finansowania szkół prywatnych kosztem publicznych. Zamierzeniem była zmiana roli rządu - od prowadzenia szkół do finansowania stypendiów.

Dążąc do upowszechnienia voucherów, stosowano różne strategie: zacieranie znaczenia pojęć szkoły publicznej i prywatnej oraz granic tych sektorów szkolnictwa; argumentowanie, że placówki publiczne nie są w stanie zaspokoić wszystkich, niezmiernie zróżnicowanych potrzeb edukacyjnych uczniów; wyliczanie korzyści, które miałyby przynieść vouchery - korzyści dla wszystkich, i tych, którzy otrzymaliby tę formę pomocy i dla pozostałych; poprawa osiągnięć uczniów; maksymalizacja równości możliwości edukacyjnych (rozumianych jako preferencje) i maksymalizacja efektywności ekonomicznej. Argumenty stawały się coraz bardziej populistyczne: stworzenie możliwości wyboru szkoły dla rodzin o niskich dochodach, z mniejszości i dla niepełnosprawnych - vouchery miałyby być narzędziem sprawiedliwości społecznej.

Jednak efektywność ekonomiczna projektowana przez Bank Światowy polegałaby na zwiększeniu liczby uczniów w klasach, zwiększeniu liczby uczniów przypadających na jednego nauczyciela, nauczaniu jednym frontem całej klasy czy obniżeniu nauczycielskich pensji, a przede wszystkim na ograniczeniu finansowania publicznego do szkolnictwa podstawowego. Strategią upowszechniania voucherów ma być również partnerstwo publiczno-prywatne, a raczej otoczenie sektora państwowego i wejście z nim w proces dyfuzji. 
W różnych publikacjach sami zwolennicy tej formy prywatyzacji szkolnictwa przyznają, że chodzi o pomoc małej liczbie uczniów np. z rodzin biednych, czy że kwoty przeznaczone na vouchery są symboliczne - jak zawsze. Ponadto przyznają, iż reforma „wyboru rodziców” nie jest programem edukacyjnym, sam wybór nie poprawia ocen.

Ciągle mało jest badań skutków reformy, a publikacje jej zwolenników są stronnicze i obarczone wieloma błędami metodologicznymi. Jedno jest pewne vouchery stanowią dodatkowy mechanizm stratyfikacji w szkolnictwie amerykańskim, które było już niezmiernie ustratyfikowane. Wspólna szkoła jest w Stanach Zjednoczonych mitem.

Z omawianej formy pomocy korzystały przede wszystkim klasy średnie i wyższe, rasa biała. Tylko 29\% rodziców o niskich dochodach przyjęło oferowane vouchery, a ponadto $40 \%$ uczniów z tych rodzin wracało do szkół publicznych. Pokrycie 50\% kosztów czesnego było poza zasięgiem możliwości ich rodziców.

Wyboru dokonują w zasadzie szkoły, a nie rodzice. Wykluczają uczniów biednych, sprawiających kłopoty wychowawcze, z niskimi ocenami czy niepełnosprawnych. Niektóre szkoły prywatne w ogóle nie chcą przyjąć uczniów z voucherami.

Jeżeli chodzi o osiągnięcia uczniów, to dominują konkluzje, że analizowana reforma nie doprowadziła do ich poprawy. Poparcie dla voucherów w społeczeństwie zmniejsza się, a i tak ich skala była niewielka i miały one charakter eksperymentalny.

Mimo przytoczonych wniosków neoliberalni ekonomiści z samouwielbieniem piszą na przykład: „poprawa osiągnięć uczniów bez pogarszania ocen innych, to piękno perfekcyjnej konkurencji rynkowej”. „Geniusz konkurencyjnych rynków polega na tym, że takie placówki (złe - E. P. ) wypadają z rynku” (Betts, 2005: 25-26).

Tymczasem Steven Macedo, teoretyk polityki, stwierdza: „Zdrowie naszego społeczeństwa politycznego wymaga szkół, które mogą uczyć, jak negocjować granice kulturowe i promować większą sympatię między obywatelami (...) to jest kluczowa praca polityczna. Gdzie ta praca może być wykonywana, jeżeli nie we wspólnych szkołach?” (Macedo 2000: 263). Jednak Patrick Wolf znalazł pewne dowody, że szkoły wybrane są równie efektywne w kształtowaniu wartości obywatelskich, jak publiczne (Wolf 2005: 210).

Phi Delta Kappan Center on National Education Policy stwierdził, że Amerykanie wprowadzili szkoły publiczne, by zjednoczyć naród i działać dla dobra wspólnego. Jeżeli będziemy postępować zgodnie z propozycjami, które nie odpowiadają duchowi historii, to możemy stracić wiele cech szkolnictwa publicznego, o których wcześni liderzy sądzili, że są konieczne dla utworzenia silnego, spójnego i sprawiedliwego narodu (Flam, Keane, 1994: 125).

Whitty, Powell i Halpin (1998), badając skutki polityki wyboru rodziców w Stanach Zjednoczonych, Wielkiej Brytanii, Australii, Nowej Zelandii i Szwajcarii, doszli do konkluzji, że powstaje coraz bardziej segregacyjna hierarchia szkol- 
na. „Wybór rodziców” zmienił się w „wybór szkoły”, dobierającej sobie najbardziej pożądanych rodziców i uczniów a odrzucając innych. Szkoły „tonące” toną coraz bardziej, a szkoły faworyzowane zbierają „śmietankę”, stają się coraz bardziej uprzywilejowane (Hill, 2004: 6). Długoterminowe zdrowie edukacji zawsze będzie spoczywało na sektorze publicznym. Ponad 30 lat neoliberalizmu wcisnęło jednak prywatyzację także do szkolnictwa (Dalton, 2012: 160). Na ogół podkreśla się, że neoliberalizm jest największą siłą w aliansie wprowadzającym reformy rynkowe (Apple, 2006: 214; Carnoy, 2000, 2001, 2003: 339; Spring, 2002, 2008: 343). Sam Bank Światowy wzywał do zastosowania neoliberalnej ekonomii w całym sektorze oświatowym (Woodhouse, Howard, 2011: 220). Instytucja ta uzewnętrzniła swoją wiarę w „pieniężny kod wartości”. Preferuje automatyczne poszukiwanie i akceptowanie pieniędzy jako niekwestionowanego dobra. Pieniądze traktowane są jako początek i koniec sekwencji regulującej myślenie i działania. Slogan „ekonomia oparta na wiedzy” w rzeczywistości oznacza komercję rządzącą wiedzą (McMurtry, 1998: 9, 32, 174, 299). Jednak BŚ twierdzi, że sama komercja nie zniekształca kierunków zmian edukacji i kultury.

Do rzadkości należą zdania takie, jak Steinera-Khamsi, że neoliberalizm nie ma tak bezpośredniego wpływu na edukację, jak się powszechnie zakłada (Steinera-Khamsi, 2010: 334-335).

Opozycja przeciw voucherom jest bardzo silna. Należą do niej związki zawodowe nauczycieli, wszystkie grupy zawodowe pracujące w szkolnictwie publicznym, bardzo wielu pracowników nauki - przede wszystkim pedagogów czy obrońcy praw człowieka i rodzice. Nie wszystkie grupy wymieniłam.

\section{Literatura}

Apple M.W. (2006). Educating the "Right” Way. Markets, Standards, God and Inequality. New York

Arnove R.F. (1999). Introduction: Reframing Comparative Education: The Dialectic of Global the Local. [W:] Comparative Education. The Dialectic of the Global and the Local. Red. R.F. Arnove, C.A. Torres. New York

Ascher C., Fruchter N., Berne R. (1996). Hard Lessons: Public Schools and Privatization. New York

Belfield C.R., Levin H.M. (2005). Privatizing Educational Choice. Consequences for Parents, Schools and Public Policy. Boulder

Belfield C.R., Levin H.M. (2007). The Price We Pay. Economic and Social Consequences of Inadequate Education. Washington, D.C.

Berman E.H. (1999). The Political Economy of Educational Reforms in Australia, England and Wales and the United States. [W:] Comparative Education. Red. R.F. Arnove, C.A. Torres. New York

Betts J.R. (2005). The Economic Theory of School Choice. [W:] Getting the Choice Right. Ensuring Equity and Efficiency in Education Policy. Red. J.R. Betts, T. Loveless. Washington, D.C. 
Betts J.R., Goldhaber D., Rosenstock L. (2005). The Supply Side of School Choice. [W:] Getting the Choice Right. Ensuring Equity and Efficiency in Education Policy. Red. J.R. Betts, T. Loveless. Washington, D.C.

Berube M.R. (1991). American Presidents and Education. New York

Brighouse H. (2000). School Choice and Social Justice. Oxford

Campbell D.E. (2006). School Choice And Social Cohesion. [W:] Choice and Competition in American Education. Red. P.E. Peterson. New York

Carnoy M. (1999). Globalization and Educational Reform: What Planners Need to Know. Paris

Carnoy M. (2000). School Choice? Or Is It Privatization?. „Educational Researcher” Vol. 29, No. 7

Carnoy M. (2001). Do Vouchers Improve Failing Public Schools?. [W:] School Vouchers: Examining the Evidence. Red. M. Carnoy. Washington, D.C.

Carnoy M. (2003). Does Privatization Improve Education? [W:] Choosing Choice: School Choice in International Perspective. Red. D.W. Plank, G. Sykes. New York

Carnoy M., Levin H.M. (1985). Schooling and Work in the Democratic State. Palo Alto

Carr M. (2011). The Impact of Ohio's Edchoice on Traditional Public School Performance. „The Cato Journal" Vol. 31, No. 1

Chubb J.E. (2006). The Private Can Be Public. [W:] Choice and Competition in American Education. Red. P. Peterson. New York

Chubb J.E., Moe T. (1990). Politics, Markets and America's Schools. Washington D.C.

Chubb J.E., Moe T. (1997). Politics, Markets and Equality in Schools. [W:] Reducing Poverty in America. Thousand Oaks

Clotfelter Ch.T. (2001). Are Whites Still Flying? Racial Patterns and Enrolment Shifts in Urban Schools, 1987-1996. „Journal of Policy Analysis and Management” Vol. 20

Coleman J.S. (1992). Some Points on Choice in Education. „Sociology of Education” Vol. 65, October

Comparative Education. The Dialectic of the Global and the Local. (1999). Red. R.F. Arnove, C.A. Torres.New York

Corwin R.G., Schneider J.E. (2005). The School Choice Hoax. Fixing America's Schools. Westport

Coulson A. (1994). School Choice. New Haven

Coulson A. (1999). Market Education: The Unknown History. New York

Dalton B. (2012). Grade Level and Science Achievement: US Performance in Cross-National Perspective. "Comparative Education Review”, Vol. 56, No 1

Digest of Education Statistics 1999, 2000, Washington D.C.

Farrel J.P. (1999). Changing Conception of Equality of Education. Forty Years of Comparative Evidence. [W:] Comparative Education. Red. R.F. Arnove, C.A. Torres. Langham

Flam S., Keane W. (1994). Public Schools, Private Enterprise. What We Should Know and What Do About Privatization. Lancaster

Friedman M. (1962). The Role of Government in Education.[W:] M. Friedman. Capitalism and Freedom. Chicago

Fuhrman S.H. (2003). Riding Waves, Trading Horses. The Twenty Years to Reform Education. [W:] A Nation Reformed? Red. D.T. Gordon, P. Albjerg-Graham. Cambridge

Getting Choice Right. Ensuring Equity and Efficiency in Education Policy. (2005). Red. J.R. Betts, T. Loveless. Washington, D.C.

Gill B.P. (2005). School Choice and Integration. [W:] Getting Choice Right. Red. J.R. Betts, T. Loveless. Washington, D.C. 
Gill B.P., Timpane M.P., Brewer D.C. (2001). Rhetoric Versus Reality. What We Know and What We Need To Know about Vouchers and Charter Schools. Santa Monica

Glazer N. (2003). The American Way of School Reform. [W:] A Nation Reformed? Red. D.T. Gordon, P. Albjerg-Graham. Cambridge

Goldhaber D., Guin K., Henig J., Hess F., Weiss J. (2005). How School Choice Affects Students Who Do Not Choose? Washington, D.C.

Grossman P. (2003). Teaching: From a Nation at Risk to a Profession at Risk? [W:] A Nation Reformed? Red. D.T. Gordon, P. Albjerg-Graham. Cambridge

Hamilton L.S., Guin K. (2005). Understanding How Families Choose Schools. [W:] Getting Choice Right. Red. J.R. Betts, T. Loveless. Washington, D.C.

Hanushek E.A. (1996). Student Resources and Student Performance. [W:] Does Money Matter? Red. G. Burtless. Washington, D.C.

Hanushek E.A., Lindseth A.A. (2009). Schoolhouses, Courthouses and Statehouses. Solving The Funding-Achievement Puzzle in America's Public Schools. Princeton

Hassel B.C. (2006). Charter Schools: Mom or Pops or Corporate Design. [W:] Choice and Competition in American Education. Red. P. Peterson. Lanham

Hedges H.V., Laine R.D., Greenwald R. (1994). Does Money Matter? A Meta-Analysis of Studies of the Effects of Differential School Inputs on Student Outcomes. „Educational Reasercher” Vol. 23, No. 3

Henig J.R. (2005). Understanding the Political Conflict Over School Choice. [W:] Getting Choice Right. Red. J.R. Betts, T. Loveless. Washington, D.C.

Hess F.M., Loveless T. (2005). How School Choice Affects Student Achievement. [W:] Getting Choice Right. Red. R. Betts, T. Loveless. Washington, D.C.

Heyneman S. (2005). The History and Problems in The Making Education Policy at the World Bank. [W:] Global Trends in Education Policy. Red. D.P. Baker, A. Wiseman. Amsterdam

Hill D. (2004). Educational Perversion and Global Neo-liberalism: A Marxist Critique. http:// clogic.eserver.org/2004/hill.html (dostęp: 21.11.2009)

Hill P.T. (2001). Introduction. [W:] Rhetoric Versus Reality. Red. B.P. Gill, M.P. Timpane, D.C. Brewer. Santa Monica

Hill P.T., Pierce J., Guthrie J. (1997). Reinventing Public Education: How Contracting Can Transform America's Schools. Chicago

Howell, W.G., Peterson P.E. (2002). The Education Gap. Vouchers and Urban Schools. Washington, D. C.

Hoxby C.M. (2000). Would School Choice Change the Teaching Profession? Cambridge

Hoxby C.M. (2001). If Families Matter Most, Where Schools Come In? [W:] Primer on America's Schools. Red. T. Moe. Stanford

Hoxby C.M. (2003). The Economics Of School Choice. Chicago

Hoxby C.M. (2006). Do Vouchers and Charters Push Public Schools to Improve? [W:] Choice and Competition in American Education. Red. P.E. Peterson. Langham

Jones P. (2000). Globalization and Internationalism: Democratic Prospects for World. [W:] Globalization And Education: Integration and Contestation Across The Cultures. Red. N. Stromquist, K. Monkman. Langham

Kahlenberg R. (2000). All Together Now: Creating Middle Class Schools through Public School Choice. Washington, D.C.

Kozol J. (2005). The Shame Of The Nation. The Restoration of Apartheid Schooling in America. New York

Lemann N. (1991). A False Panacea. „Atlantic Monthly”, January 
Levin H.M. (1998). Educational Vouchers: Effectiveness, Choice and Costs. „Journal of Policy Analysis and Management" Vol. 17, June

Levin H.M. (2001) Privatizing Education. Can the Marketplace Deliver Choice, Efficiency and Social Cohesion? Boulder

Levin H.M. (2006). The Costs of Privatization. [W:] Choice and Competition in American Education. Red. P. Peterson. Lanham

Lieberman M. (1986). Beyond Public Education. New York

Mecedo S. (2000). Diversity and Distrust: Civic Education in a Multicultural Democracy. Cambridge

McMurtry J. (1998). Unequal Freedoms: the Corporate Markets As an Ethical System. Toronto

Merrifield J. (2001). The Schools Choice Wars. Langham

Mittang L.D., Connell Ch. (2001). Setting the Agenda. Education Vouchers and the Media. [W:] Privatizing Education. Red. H.M. Levin. Boulder

Moe T. (2001). Private Vouchers: Politics and Evidence. [W:] School Choice or the Best Systems. What Improves Education? Red. M.C. Wang, H.J. Walberg. New York

Moe T. (2001b). Schools, Vouchers and American Public. Washington, D.C.

Moe T. (2006) A Union by any Other Name. [W:] Choice and Competition in American Education. Red. P.E. Peterson. Lanham

Moore D., Davenport S. (1998). Choice: the New Improved Sorting Machine. Madison

Morrow R.A., Torres C.A. (1999). The State, Social Movements and Education Reform. [W:] Comparative Education. Red. R.F. Arnove, C.A. Torres. Langham

Mundy K. (2007). Education For All: Paradoxes And Prospects Of A Global Promise. [W:] Education for All: Global Promises, National Challenges. Red. D.P. Baker, A.W. Wiseman. Amsterdam

Murphy D., Nelson H.F., Rosenberg B. (1997). The Cleveland Voucher Program: Who Choses? Who Gets Choosen? Who Pays? New York

Myers D.E. (2001). Criteria For Evaluating School Voucher Studies. [W:] Privatizing Education. Red. H.M. Levin. Boulder

Natriello G. (2001). Vouchers, Privatization and the Poor. [W:] Privatizing Education. Red. H.M. Levin. Boulder

Patrinos H., Barrera-Osorio F., Guaqueta J. (2009). The Role and Impact of Public-Private Partnership in Education. Washington, D.C.

Petersman E.U. (2000). The WTO Constitution and Human Rights, „Journal of International Economic Law" Vol. 3, No. 25

Peterson P.E. (2006a). Reforming Education in Florida. Stanford

Peterson P.E. (2006b). Choice and Competition in American Education. Lanham

Rawls J. (1994). Teoria sprawiedliwości. Warszawa

Rouse C. (1998). Comment (to) T. Loveless, The Use and Misuse of Research in Educational Reform. [W:] Education Policy. Red. D. Ravitch. Washington D.C.

Rothstein L.F. (1999). School Choice and Students with Disabilities. [W:] School Choice and Social Controversy. Red. S.D. Sugarman, F.R. Kemerer. Washington D.C.

Rust V., James J. (2005). Globalization and Educational Policy Shifts. [W:] International Handbook on Globalization and Policy Research. Red. J. Zajda. Dordrecht

Samoff J. (1999). Institutionalizing International Influence. [W:] Comparative Education. Red. R.F. Arnove, C.A. Torres. Lanham

Sarason S. (1990). The Predictable Failure of Education Reform. San Francisco

Schneider M. et al. (1998). Shopping for Schools: in the Land of the Blind, The One-Eyed Parent May Be Enough. „American Journal of Political Science” Vol. 42, July 
Schneider M., Teske P., Marschall M. (2000). Choosing Schools: Consumer Choice and the Quality of American Schools. Princeton

School Choice: A Special Report. (1992). Princeton

Smith K.B., Meier K.J. (1995). The Case Against School Choice: Politics, Markets and Fools. Armonk

Smith M.S., Scoll B.W. (1995). The Clinton Human Capital Agenda. „Teachers College Record 96" Spring

Spring J. (2002). Political Agendas for Education: From the Religious Right to the Green Party. Mahwah

Spring J. (2008). Research on Globalization and Education. „Review of Educational Research” Vol. 78 , No. 2

Steiner-Khamsi G. (2010). The Politics and Economics of Comparison. „Comparative Education Review" Vol. 54, No. 3

Tough Choices, Tough Times. The Report of the New Commission on the Skills of the American Workforce. (2007). Washington, D.C.

Tucker M. (2004). Reaching for Coherence in School Reform. The Case of America's Choice. [W:] Expanding the Research of Education Reforms. Perspectives From Leaders of The Scale-Up of Educational Interventions. Red. T.K. Glennan Jr., J. Bodily, J.R. Galegher, K.A. Kerr. Santa Monica

Vestergen D.A. Clark D. L. (1998). The Diminution In Federal Expenditures for Education During the Reagan Administration. „Phi Delta Kappan” October

West M.R. (2003). The Future of Tax Credits. [W:] The Future of School Choice. Red. P.E. Peterson. Stanford

Wexler P. (1987). Social Analysis of Education: After the New Sociology. London

Whitty G., Power S., Halpin D. (1998). Devolution and Choice in Education: the School, the State and the Market. Buckingham

Witte J.F. (2000). The Market Approach to Education: An Analysis of American First Voucher Program. Princeton

Wolf P. J. (2005). School Choice and Civil Values. [W:] Getting Choice Right. Red. J.R. Betts, T. Loveless. Washington D.C.

Woodhouse H. (2001). Ultimately Life is Not for Sale. „Interchange” Vol. 33, No. 3

Woodhouse H. (2011). Your Money or Your Life! A Critical Canadian Perspective on the World Bank ,Reform Agenda” for Higher Education. „Journal of International Education, Spring

Zupan M.A. (2011). The Virtues of Free Markets. „Cato Journal” Vol. 31, No. 2 Zupan M.A. (2011). The Virtues of Free Markets. „Cato Journal” Vol. 31, No. 2

\section{Private Might Be Public? Vouchers - the Most Radical Form of Privatization in American Education}

\section{summary}

The millieu of pedagogists perceives privatization as a possibility of providing public services without considering the lower quality of these services. It is being perceived as a general ideological pressure to diminish the role of government. Americans desire service with low costs and less involvement of government. There's been a shift in this matter in public thinking. Never- 
theless, there must be a redefinition of what is to be provided by the government. Fundamental debates are currently in progress on the need of a clear vision an the mission of education. The society dwells on what should be expected from the public education. Even Nathan Glazer, a prominent Harvard scholar and the advocate of schools for everyone, came eventually to the conclusion that public schools are not able to such an organization to meet conflicted needs and values of the citizens: religious and secular, permissive and traditional, those looking for new experiences and those looking for safety and stability.

The concept of vouchers has been introduced for the first time by Milton Friedman in 1955. His intention was to increase the productivity of schooling and to solve the problem of state monopoly controlling educational institutions. According to Friedman schooling administration is not very interested in providing the best product for the lowest price. If parents could use the publicly financed vouchers to cover the whole or the partial costs of education in private schools, then public institutions will be forced to compete and to strive for clients. They will be also forced to improve its work, increasing productivity, financial effectiveness and to satisfy their clients. Rose and Milton Friedman had started a foundation which only goal was to legalize a legal act, which introduced vouchers in the system of public education and other forms of choosing a school.

In this light private schools are focused on their educational tasks and thanks to this provide better products. Effective schools have clearly set goals, rigorous academic standards, there's an order and discipline, as well a lot of home work, there are high expectations towards the pupils, a strong leadership of the school's principal, teachers participate in decision making and get good along with parents. Schools superintendent and administration control less the schooling program, methods, hiring teachers and disciplines standards. The enthusiasts of free market in education had noted significantly big differences between public and private institutions in midtowns of grand cities, with a dominance of ethnic and racial minorities. However they did not investigate the described sectors of education and did not made any empirical comparisons, what led to their critique.

The voucher movement is the most politicized and marketed reform of American education since the Reagan administration. It was very clearly directed by neoliberals. A significant example might the Friedman Foundation which opted for legalizing this form of privatization. The reform itself started with the increase in public financing of private schools with the loss of the public ones. The goal was to change the role of government - from being in charge of schools to financing scholarships.

While striving for the popularization of vouchers various strategies had been obtained: effacing the meaning of public and private schools and the boundaries of these sectors of schooling; arguments that public institutions are not able to satisfy all, very diverse, educational needs of pupils; counting the advantages brought by the vouchers; improvement of pupil's efficiency etc. These arguments became more and more populist: creating the possibility to choose a school by families with low incomes, those from the minorities and disabled - the vouchers were supposed to be a tool for social justice.

However the effectiveness designed by the World Bank was supposed to be based on increasing the number of students in classes, a uniform teaching of the whole class or lowering teacher's wages, but first of all the public finance cuts for elementary schooling. The strategy for popularizing vouchers was also public-private cooperation or rather opening the state sector and coming into the process of diffusion with it.

In many texts the advocates of this form of privatization of schooling admit that it is all about helping a small group of pupils (for example those coming from poor families) or that the 
sums of money dedicated to vouchers are purely symbolic (as usual). They also admit that the reform of "parents choice" is not an educational program - the choice itself does not improve the notes.

There is still little research on the consequences of the reform and the works of its supporters are being plagued by taking sides and many methodological errors. One is sure - vouchers are making an extra mechanism of stratification in American education, which already was very stratified. A coomon school in the United States is a myth. From the described reform benefited just the white middle and higher classes. Only $29 \%$ of parents with low incomes accepted the offered vouchers and over $40 \%$ of students from those families came back to public schools. Covering over $50 \%$ of the fee was out of their reach. The choice is made basically by schools not the parents. They exclude poor pupils, troublemakers, those with bad notes or the disabled ones. Some private schools do not want to accept pupils with vouchers at all.

When it comes to students achievements conclusion dominate saying that the reform did not contribute to their improvement. The social support for vouchers is decreasing and the scale was small anyway as the vouchers were just experimental. However, despite the presented conclusions neoliberal economists write with emphasis that for example: "the improvement of students achievements without the decrease of notes of others is the beauty of free market competition" or "the genius of competitive markets lies upon the fact that (bad) institutions fall off the market" (Betts, 2005: 25-26). At the same time Steven Macedo, a theorist of politics, states that: "the health of our political society demands schools, which are able to learn how to negotiate cultural boundaries and to promote greater sympathy among citizens (...) this is the key political work. Where this work can be done if not in common schools?" (Macedo, 2000: 263).

Whitty, Powell and Halpin (1998) while researching the effects of politics of parents choice in the United States, United Kingdom, Australia, New Zealand and Switzerland came to the conclusion that a even more segregationist school hierarchy emerges. „Parents choice” turned into "schools choice", which selects the most desired parents and pupils and rejecting all others. "Drowning" schools drown even more, and those favourized gather the "cream" and become more privileged (Hill, 2004: 6). Long term health of education will lie upon the public sector. Over 30 years of neoliberalism did however pushed privatization into schooling (Dalton, 2012: 160). Generally it is being stressed out that neoliberalism is the most significant force in the alliance introducing the market reforms. Money is being treated as the beginning and the end of the sequence that regulates thinking and acting.

The opposition against vouchers is very strong. It gathers teachers work unions, all professional groups working in the public schooling, many academics and researchers (foremost pedagogists or human rights activists) and parents. 
